NBER WORKING PAPER SERIES

\title{
EURO-PRODUCTIVITY AND EURO-JOB SINCE THE 1960S: WHICH INSTITUTIONS REALLY MATTERED?
}

\author{
Gayle J. Allard \\ Peter H. Lindert \\ Working Paper 12460 \\ http://www.nber.org/papers/w12460 \\ NATIONAL BUREAU OF ECONOMIC RESEARCH \\ 1050 Massachusetts Avenue \\ Cambridge, MA 02138 \\ August 2006
}

The authors are indebted to Matthew Pearson for able research assistance, and to seminar audiences at Berkeley, British Columbia, Copenhagen, Cornell, Harvard, Oxford, and the World Bank for helpful comments on earlier drafts. Any remaining errors are ours. For data files, see http://www.econ.ucdavis.edu/faculty/fzlinder, and click on "Allard-Lindert data sets for OECD 1950-2001." The views expressed herein are those of the author(s) and do not necessarily reflect the views of the National Bureau of Economic Research.

(C2006 by Gayle J. Allard and Peter H. Lindert. All rights reserved. Short sections of text, not to exceed two paragraphs, may be quoted without explicit permission provided that full credit, including $\odot$ notice, is given to the source. 
Euro-Productivity and Euro-Jobs Since the 1960s: Which Institutions Really Mattered?

Gayle J. Allard and Peter H. Lindert

NBER Working Paper No. 12460

August 2006

JEL No. N13, N3

\begin{abstract}
$\underline{\text { ABSTRACT }}$
How have labor market institutions and welfare-state transfers affected jobs and productivity in Western Europe, relative to industrialized Pacific Rim countries? Orthodox criticisms of European government institutions are right in some cases and wrong in others. Protectionist labor-market policies such as employee protection laws seem to have become more costly since about 1980, not through overall employment effects, but through the net human-capital cost of protecting senior male workers at the expense of women and youth. Product-market regulations in core sectors may also have reduced GDP, though here the evidence is less robust. By contrast, high general tax levels have shed the negative influence they might have had in the 1960s and 1970s. Similarly, other institutions closer to the core of the welfare state have caused no net harm to European jobs and growth. The welfare state's tax-based social transfers and coordinated wage bargaining have not harmed either employment or GDP. Even unemployment benefits do not have robustly negative effects.
\end{abstract}

Peter H. Lindert

Department of Economics

University of California, Davis

Davis, CA 95616

and NBER

phlindert@ucdavis.edu 


\title{
EURO-PRODUCTIVITY AND EURO-JOBS SINCE THE 1960s: WHICH INSTITUTIONS REALLY MATTERED?
}

\author{
By Gayle J. Allard and Peter H. Lindert
}

Western Europe's productivity and employment performance has puzzled researchers for years. Unemployment rates jumped in the 1970s, and remained high until the mid-1990s. Since then the unemployment rates have eased but are still high. Meanwhile, labor productivity advanced as well in Western Europe as in the whole OECD until 1995, but then lagged. ${ }^{i}$ In the search for explanations, most economists have focused on unemployment rates and a narrow range of variables, country experiences and time periods, with uncertain and non-robust results.

We believe that in the spirit of the new comparative economic history, a broader approach should be taken to these pressing issues, which involve the workings of entire national and regional economies. In this paper, we search eclectically for tests and avoid discarding information. While we take a broader empirical view, this paper does share a narrowness of the past literature's view of contrasts between Europe and the Pacific-Rim OECD countries. Like most writers, we focus here on possible flaws in institutions that prevail more in Europe, and not on possible flaws in other countries. Thus in the transAtlantic contrast, we shall ignore some areas where American institutions may well be inferior, such as health care, energy policy, or cell-phone service.

Our results contradict theories on the negative effects of the welfare state, and contain important messages about Europe's productivity lag and the insider-outsider divide in rigid labor markets, which is gaining visibility in Europe. Specifically, we find:

- Employee protection legislation (EPL) redistributes human capital formation away from youths and women to senior males. This shows up as a delayed loss in labor productivity rather than a net effect on jobs or unemployment.

- Product market regulations may have also reduced productivity, though this result is not yet robust. 
- Coordinated wage bargaining boosts productivity growth, presumably through its effects on wage moderation and macro-policy.

- Although tax wedges and transfer payments are often blamed for slow European job growth, we find that tax and transfer packages in high-spending welfare states have no clear cost in jobs or in productivity. Past studies showed negative effects because they failed to separate transitory from durable effects, and because some accepted theory as an empirical test.

Our paper broadens the empirical debate in several ways. First, we examine effects on jobs and productivity together, which sheds extra light on both. This is a crucial step missed by two past literatures: the labor-market literature on European unemployment, and the GDP-growth literature. We also combine institutions that have been considered separately in the labor market or growth literature. Finally, we offer new historical estimates of two labor-market institutions and new econometric tests, which point to a new reading of the verdicts on different institutional suspects. Past studies missed some of these verdicts by discarding fixed effects as mere control variables, when they in fact offer telling clues on the roles of different institutions. Our conclusions counter some of the recent pessimism about the usefulness of international macro-panel evidence.

\section{Two Court Trials That Should Be One}

\section{$\underline{\text { A. Euro-jobs as victims }}$}

The debate over the causes of European unemployment has raged for a quarter century. In the 1960s, unemployment was considered a bigger problem in the United States, and many pointed to Europe's central controls as the reason for its full employment. This view was dramatically reversed in the 1970s, and it soon became clear that the oil shocks alone could not explain the persistence of double-digit European unemployment rates through the 1980s and 1990s. ${ }^{\text {ii }}$ Meanwhile, labor productivity grew faster in Europe up to 1995, and the popular view was that Europeans worked less than Americans, but almost as productively. In the early $21^{\text {st }}$ century, the job and productivity winds shifted. Unemployment stayed high in some European countries and dropped 
below the United States and Japan in others; and flagging European productivity became a new concern.

Not surprisingly, the literature exploring the Euro-jobs issue is vast. ${ }^{\mathrm{iii}} \mathrm{We}$ introduce only a few strands, and the difficulties they have encountered in analyzing joblessness in the leading industrialized countries. The Organization for Economic Cooperation and Development (OECD) has been at the center of research on comparative unemployment, providing the key data for investigating these issues and joining the policy debate. Its efforts have delivered a Washington Consensus package of policy conclusions: Europeans have lost their jobs to product and labor market rigidities, high tax rates on labor, and over-generous unemployment compensation and early retirement subsidies. ${ }^{\text {iv }}$ These orthodox conclusions emerged from ground-level observation of individual country programs, micro-econometric studies of labor supply behavior, and international macro-panel data on OECD countries from 1980 or earlier.

Baker et al. (2005) and Freeman (2005) level serious criticisms at the OECDpanel econometric literature. They suggest that OECD economists and others entered the statistical laboratory with biased glasses, possibly adjusting their institutional measures of employment protection, product market regulation, and openness to fit their prejudice. Baker et al. note that the same researchers downplayed their econometric findings that coordinated wage setting and active labor market policies have favorable job effects. They conclude that there is "a yawning gap between the confidence with which the case for labor market deregulation has been asserted and the evidence that the regulating institutions are the culprits." ${ }^{\prime v}$ Freeman calls for forsaking the macro-panel approach in favor of micro-economic studies of individual country labor markets.

A key message of these studies and others is that econometric analysis on international panels is unlikely to yield clear answers. Blanchard and Wolfers (2000) say a key reason for this failure is that the institutional variables are essentially fixed country effects which cannot explain the dramatic rise in European unemployment across the 1970s and 1980s. ${ }^{\text {vi }}$ Heckman and Pagés (2004) express the same skepticism -- 
"The fragility of the macro-based estimates ... suggests one reason why relatively little is known about the impact of regulations in Europe, despite an abundance of cross-country time series papers analyzing policies in that region.",vii

\section{B. Euro-GDP as Victim}

In contrast, the literature on comparative economic growth is less agnostic about econometrics and more pessimistic about European institutions. In this literature, Western Europe lags behind North America for institutional reasons that overlap only partially with the labor-market institutions indicted in the unemployment literature. In the growth trial, the leading suspects are technology policy, telecommunications taxes and restrictions, education, taxes, the welfare state, restrictions on product-market competition, and policies toward big-box retail stores. Employee protection laws, coordinated wage bargaining and minimum wages receive little attention, even though authors who contrast European and American productivity would agree that these institutions are anti-growth. viii $^{\text {in }}$

The only overlap between the two trials is taxes and welfare-state transfers. Just as the OECD and other critics blame unemployment compensation and taxes on labor for raising unemployment, the growth literature finds that some kinds of taxes and spending reduce GDP. The most persuasive study in this genre is Kneller, Bleaney and Gemmell (1999), which classifies taxes by whether they discourage investments, and divides expenditures into uses that are productive (general public services, defense, education, health, housing, transport, communications) or unproductive (social benefits, recreation, “economic services"). Using macro-panels with attention to budget accounting constraints, the authors reach intuitively persuasive conclusions: distortionary taxes (on income, payrolls, property) hurt growth if they finance unproductive expenditures, while non-distortionary taxes (on buying goods and services) do not: and productive government expenditures enhance growth, while unproductive ones do not. ${ }^{\text {ix }}$ Hence both suspects and victims in the unemployment and growth literatures are quite different.

\section{The Case for Merging the Trials}


Since these literatures have remained separate, both have failed to pursue some potentially decisive tests. Even though each set of accusations implies effects on both jobs and GDP, researchers have missed the chance to test the employment and productivity effects of each institution together. Intuition indicates that some institutions may retard both job creation and productivity, while others should raise one and reduce the other. ${ }^{\mathrm{x}}$ Common sense also predicts that the effects should unfold with different time lags, allowing another opportunity for testing by exploring the two kinds of effects simultaneously.

The debate over employee protection legislation (EPL), which raises the costs of worker dismissal, illustrates the need to test for job and productivity effects together. Here, the unemployment literature has missed two kinds of chances. First, although theory argues that EPL creates insiders and outsiders, protecting the jobs of the former and reducing incentives to hire the latter, most writings have failed to quantify total and separate effects in this way, even though the marginal data cost is minimal. ${ }^{\mathrm{xi}}$ Any study of EPL's alleged job effects should not only estimate the impact on total jobs for insiders plus outsiders, but also estimate the effects on the two groups separately.

Exploring EPL's separate effects on insiders and outsiders takes us through a doorway that was always open but seldom traversed in the Euro-jobs debate: the doorway to exploring EPL's human capital and productivity consequences. Advocates of job protection have long asserted that EPL raises productivity by stabilizing jobs, in this case for protected "insiders". This leads them to accumulate human capital on the job, which, along with induced capital deepening, should raise GDP per worker or per hour. ${ }^{\text {xii }}$ However, strict EPL also denies new jobs to outsiders. This delays their human capital formation and reduces later productivity.

Which productivity effect dominates? The answer involves some dynamics, since the gains and losses in human capital have a different time path. The positive effects on insiders' productivity begin as soon as a law protects their jobs. This effect can continue indefinitely, as new insiders replace retiring older ones. The negative effect on outsiders' productivity, however, probably worsens over time before stabilizing on a per-capita basis. The longer that EPL denies work to outsiders, who are often young, female or immigrant job-seekers, the greater is their loss of human capital. This loss will persist 
throughout the outsiders' careers, even after they eventually become insiders; in fact, the job interruption literature suggests that they may never fully catch up. ${ }^{\text {xii }}$ So the negative human-capital effects of EPL could rise over an adult career. To evaluate these contradictory effects on productivity over time, we propose a new test: can the negative productivity effects of exogenously tightening EPL rise for two or three decades? Our results suggest that they do, making the productivity effects of older, longer-standing EPL more negative than newly instituted protections.

Other institutions also affect both jobs and productivity in ways that allow extra testing of each leading hypothesis from labor or growth economics. Standard static reasoning says that any institutional or policy change that limits labor supply should raise productivity while it reduces jobs, simply because the static labor demand curve has a negative slope. That common presumption deserves to be tested: If generous unemployment compensation, taxes on labor earnings or higher minimum wages restrict labor supply, do they raise labor productivity as static theory suggests? A more optimistic theoretical model even suggests that more generous unemployment compensation will raise both labor productivity and long-run labor supply, if the extra safety nets replace missing private insurance markets and allow persons to take more productive risk. ${ }^{\text {xiv }}$ As these examples illustrate, competing views of the effects of institutions and policies have many testable implications about both job and productivity effects.

\section{Better Measures of Labor-Market Institutions -- and the History They Reveal}

"Explanations (of high unemployment) based solely on institutions also run however into a major empirical problem: many of these institutions were already present when unemployment was low .... Thus, while labour market institutions can potentially explain cross country differences today, they do not appear able to explain the general evolution of unemployment over time."

This concern voiced by Blanchard and Wolfers (2000) has led to the view that since the institutional suspects antedate the onset of high unemployment and slow productivity growth in the 1970s, they cannot explain it. However, this view is based on 
imperfect impressions of the longer history of labor-market institutions. Better measures of the main institutions show that some of the main suspects-strict EPL, generous unemployment compensation and high tax rates-- arrived on the scene just before European jobs and productivity growth began to suffer. Even if the problems that began in the 1970s owed much to the oil shocks, the causal mechanisms cannot be uncovered without a correct charting of institutional history.

\section{A. Unemployment Compensation: The Net Reservation Wage Measure}

"It is unfortunate that we have no comprehensive time series data on the coverage of the [unemployment compensation] system or on the strictness with which it is administered." -- Nickell, Nunziata and Ochel $(2005)^{\mathrm{xvi}}$

To provide this more accurate institutional history, we start by offering improved measures back to 1950 of two key labor market institutions in OECD economies: the generosity of unemployment compensation and the strictness of employment protection legislation (EPL). ${ }^{\mathrm{xvii}}$

Unemployment compensation is clearly a work disincentive in the short run. How big a disincentive it is depends on three components of the generosity of unemployment compensation:

(a) the "replacement rate," or (benefits per recipient) divided by (market wage), net of taxes;

(b) the eligibility of the unemployed for benefits, including requirements for job search and sanctions for non-compliance set out in national law; and

(c) the duration of coverage (6 months, 1 year, etc.).

Many studies measuring unemployment compensation have focused on the replacement rate alone, omitting the other two components. Others consider duration, but still do not put the whole picture together for a long time span. We introduce estimates that incorporate all three components into a single measure of the "net reservation wage:" the 
expected value of unemployment compensation as a percent of the median market wage after taxes. $^{\text {xviii }}$

The new picture of unemployment compensation charted in Figure 1 reveals important differences in the timing of more generous benefits. Benefits rose from 1967 in most of the core countries of the European Community, especially the Netherlands and Germany. These early increases antedate the post-1973 macro-shocks. Other countries escalated benefits after the first oil shock (Sweden in 1978, Denmark and Spain in 1985, and Italy in the mid-1990s). Generous unemployment benefits never reached Greece and Portugal, or the Pacific Rim countries besides New Zealand. Clearly, unemployment compensation differed in its timing as well as in long-run national averages.

\section{B. The Strictness of Employment Protection Legislation}

Past studies have been restricted to a few limited snapshots of EPL due to lack of data $^{\mathrm{xix}}$. This study draws on one author's detailed reading of legislation through history, which was codified into an index of EPL strictness dating back to 1950. The new index reveals that job protection was neither fixed over time nor the same across countries. The view that strict EPL was already in place in the low-unemployment era before 1973 is incorrect except for Spain and Portugal, where firm EPL dates to the dictatorships of Franco and Salazar (but where democracy also brought greater job protection). Figure 2 illustrates the differences in timing across countries since 1960. As with the dole, EPL rose at varying times and to different extents across countries; and strict EPL often antedated other institutional changes and poorer macro-performance by a few years. Italy was a leader, tightening protection for workers in formal sectors in the 1960s, three decades before it instituted generous unemployment benefits. France, Germany, and the Netherlands also tightened EPL in the years of union strength and full employment between 1967 and 1973. Other countries such as Sweden, the United Kingdom and Ireland built up their legal job defenses after the first oil shock hit. Since the mid-1980s EPL, like unemployment benefits, has hardly retreated for the OECD as a whole, and cross-country differences persist. 


\section{Other Institutions}

The only labor-market institution that was already present when unemployment was low in the 1960s was coordinated wage bargaining, which brings large employer groups and organized labor together to negotiate wages and working conditions for most of the economy. Such bargains are outside of the ordinary functioning of decentralized markets and thus qualify as an interventionist institution, even when the government does not participate. To plot the history of coordinated wage bargaining, we use recent estimates by Ochel (2000). ${ }^{\mathrm{xx}}$ Over the last four decades of the $20^{\text {th }}$ century, the nature of coordinated wage bargaining was stable for about half the OECD countries: some clung to coordination, and others consistently rejected it. In some cases coordinated bargaining broke down, the main examples being Spain and Portugal after the dictatorships, Britain in the Thatcher revolution, and New Zealand in 1990. In Scandinavia it weakened, yet did not collapse. In contrast, it strengthened in Ireland in the 1990s. For the OECD as a whole, there was very little trend in the degree of coordination.

Other government institutions rose gradually in importance, especially after the onset of the oil shocks. Tax rates and tax wedges on labor earnings followed the upward path noted in the generosity of unemployment compensation. Active labor market policies, such as subsidies for retraining and job search, rose later, from the mid-1980s. The only interventionist policy that tapered off was product market regulation, for which a seven-sector index developed by the OECD shows gradual declines since 1980.

\section{Better Tests}

With improved institutional measures in hand, our next step is to expand the range of tests. We will concentrate on macro-panel tests in this and the next section despite the pessimism about the effectiveness of international macro-panels for judging national institutions. We agree that micro-studies for individual countries can yield important evidence if they draw on true policy experiments: and we cite such studies below. Yet better evidence can be squeezed from the international contrasts than recent authors have acknowledged. 
Our specifications of the determinants of international job and productivity performance differ from those in past studies. However, our most durable results do not depend on the details of variable inclusion or functional form. The main points emerge simply because we combine job and productivity determinants into a single system, we re-test with different periods and countries, and we re-interpret fixed effects that also showed up in other studies.

\section{A. The Basic Equation Set}

We explore the effects of a common set of control variables and institutions on jobs, productivity, and growth using the following basic equation defined over $\mathrm{j}=(1, \ldots$, $\mathrm{J})$ countries and $\mathrm{t}=(1, \ldots, \mathrm{T})$ time periods:

$$
Y j t=\beta k X k j t+u j t
$$

where the Y's are the job and productivity variables to be explained, the Xk's are $\mathrm{k}$ identified influences on the Y's, and the ujt's are the error terms. The choice of behavioral X's should envelope competing theories. The X's can be instrumented or not, and can have time lags or not. The choices of X's depend on data availability, as do the countries and time periods. To reduce serial correlation, we use three-year averages as the time dimension of each observation. More complete data permits us to span the 1963/1965 - 1999/2001 period in a single set of equations. However, for the following discussion we split that long span into two overlapping samples (1963/1965 - 1978/1980 and 1978/1980 - 1999/2001) due to structural shifts that will not be difficult to interpret.

The independent influences (Xk's) on jobs, productivity, and growth are summarized in Table 1. The dependent variables are the five job outcomes, four productivity and GDP outcomes, and one growth rate listed at the top of the table. Next come some control variables often used in the literature. For most equations the lagged dependent variable must be included, since the behavior of jobs and productivity depends strongly on influences that also influenced the previous period's jobs and productivity. One can deal with this feedback in various familiar ways, including first differencing. One of these differencing approaches is the simple growth equation in the middle 
column. We will not explore complete first differencing here, since we will argue that the fixed country effects that differencing is designed to finesse often contain vital information for judging institutions.

The other control variables are familiar. The lagged term for GDP per capita relative to the United States, a proxy for catching-up potential, will have the effects one expects from the growth convergence literature: a poorer recent past lowers current productivity but raises the growth rate. Educational attainment is a familiar source of productivity, though its influence is sometimes obscured in our regressions by the inclusion of the lagged dependent variable. The age shares of the very young and very old also have familiar effects on employment and productivity.

Aggregate demand and aggregate supply shocks strongly affect jobs and productivity in all studies. Those shocks can be national or global, and macroeconomists proxy them in various ways. We take a cautious approach, capturing key influences while minimizing risk of simultaneity bias. We proxy aggregate demand shocks with OECDwide inflation minus unemployment, and aggregate supply shocks with the familiar "misery index," the sum of inflation and unemployment at the same global level.xxi

Next Table 1 lists the institutional and budgetary variables at the center of the debates over Euro-jobs and Euro-growth. Product market institutions and policies are represented by the OECD index of product-market regulation, and by the Freedom House index of business leaders' opinions on the openness of the country's markets. The OECD regulation index covers seven basic sectors (airlines, telecommunications, electricity, gas, post, rail, and road freight), but omits sectors that have stood out in recent technological advances, such as retailing. Arguably these omitted sectors grew faster in the United States than in Europe because of European regulations on land use and work hours. The Freedom House measure of openness seems appropriate here since it tries to capture policy and not geography. However, this variable explains little because it has been almost constant in the OECD countries since the 1970s.

We use the long reach of our new EPL estimates to capture the possible dynamics of employment protection laws. As conjectured above, EPL may save jobs and encourage productivity in the first few years, when it protects working-aged men and increases their human capital. However, it could cost jobs and productivity later, as the share of 
unprotected youths and women in the labor force rises. To explore the dynamics and test for the durable net effects, we use just one level of lagged EPL and a couple of changes in EPL. The level is the oldest, with a 12-year lag.

Next comes the Ochel index of coordination in functional forms designed to test some ideas in the literature. One idea dating back at least to Calmfors and Driffil (1988) is that wage-setting coordination has a U-shaped effect on jobs. It promotes employment at the two extremes, when bargaining is either fully decentralized or centralized; while semi-coordinated bargaining is predicted to cost jobs. ${ }^{\text {xii }}$ We can test this, and also test whether EPL and coordinated bargaining, which both pursue stable jobs and costs, are substitutes or complements.

The conventional view on budgetary policies is that any higher taxes or transfers cut jobs, and some of them reduce productivity as well. The main budgetary suspects are tax rates on productive labor and subsidies to the unemployed. As prominent as this suspicion is, surprisingly few studies test for a familiar corollary: The output loss from a tax wedge or a non-work subsidy should increase non-linearly. Perhaps this frequent oversight is another casualty of emphasizing job effects at the expense of output effects. The corollary can be tested, and we use cubic functions to explore the differences in the effects of consecutive tax or transfer increases of the same size.

In addition to the total tax burden and unemployment compensation, we explore the effects of the tax and spending mix. On the tax side, we follow the shares of income and property tax and consumption taxes, and omit social security contributions. On the expenditure side, we follow the share of social transfers and omit non-social expenditures plus net budget surplus minus non-tax revenue.

\section{B. Durable and Transitory Influences}

As some theories hint, we should be prepared for the possibility that a particular $\mathrm{k}$ th independent variable $\mathrm{Xk}$ has different slopes for its durable influence (call it Xkd) and its transitory residual (xkjt). That kind of split is important whenever behavior reacts differently to durable and transitory influences, as in Milton Friedman's permanent income hypothesis of the consumption function. Therefore we prefer this generalization of the basic equation: 


$$
\text { Yjt }=\text { Bkxkjt }+ \text { Ak Xkd }+ \text { ujt. }
$$

Sometimes researchers are lucky, and find that the two component parts of Xkjt have the same coefficients, so that each $\mathrm{Bk}=\mathrm{Ak}=ß \mathrm{k}$, yielding the usual kind of panel equation in Equation (1): Yjt $=ß \mathrm{k} X \mathrm{Xjt}+\mathrm{ujt}$. Yet that is not the case in recent OECD experience, so we need to distinguish durable from transitory effects.

Durable influences pose an econometric challenge. The estimation task gets complicated if the durable influences ( $\mathrm{Ak} \mathrm{Xkd}$ ) behave like linear combinations of conventional fixed place binaries and fixed time binaries, as with the budgetary variables here. When this happens, Equation (2) behaves like

(3) $\mathrm{Yjt}=\mathrm{Bkxkjt}+\mathrm{Ckj} \mathrm{Xkj}+\mathrm{Dkt} \mathrm{Xkt}+\mathrm{Uj}+\mathrm{Vt}+$ ejt

where the Bs, Cs and Ds are coefficients, the Xkj's are fixed country profiles of the durable influences, the Xkt's are fixed time profiles of the durable influences, $\mathrm{Uj}$ and $\mathrm{Vt}$ are vectors of coefficients on conventional place and time binaries, and ejt is the new error term. A serious identification problem will loom in this case, because the durable behavioral influences (Xkj and $\mathrm{Xkt}$ ) will be linear combinations of the conventional fixed effect binaries. We cannot separately estimate $\mathrm{Xkj}$ and $\mathrm{Uj}$, or $\mathrm{Xkt}$ and $\mathrm{Vt}$. We return to this complication in a later section, after we examine the results from omitting conventional fixed effects in the spirit of Equation (2).

To underline the important difference between durable effects (Ak Xkd) and transitory effects (Bk xkjt) and their problematic relationship to conventional fixed effects, consider an analogy to the econometrics of the familiar consumption function. Suppose that we had data on the consumption, income, and other attributes of 500 people in a panel of 10 years, and we were asked to estimate what a permanent income gain would do to consumption. The permanent income hypothesis or the similar life-cycle hypothesis teach us that the marginal propensity to consume is much higher when income is permanently raised than when it is raised only one year. Yet the standard approach to pooled estimation throws in fixed effects for individuals or places plus fixed time effects 
and then discards them, reporting only the slope with respect to transitory changes. In the consumption function case, that would amount to hiding the long-run marginal propensity to consume of perhaps 0.9 , and then presenting the transitory slope of perhaps 0.2 as the predicted effect of raising income permanently. The usual way of hiding the more durable effect is to shorten the regression table by simply indicating whether or not fixed effects were added to the equation. Yet fixed effects are often the closest approximation to the effects of durable influences that could be proxied by long-run moving averages. This difference, as we shall see, matters greatly to the debate over European institutions. We return to it when confronting the possible role of fixed effects in the international macroestimates of job and productivity determinants.

\section{Revealed Impacts on Euro-Jobs and Euro-Productivity, 1978-2001}

\section{A. The Basic Verdicts}

Our international macro-panel tests, approached on these terms, offer new insights on which institutions matter and which do not. Although we encounter some of the ambiguities that have bothered past authors, eclecticism offers a net gain in the end, once we have presented slightly better tests, separated durable from transitory influences, extended the time perspective, and visited other countries. We begin with the same data period as most studies, starting from 1980 and ending in 2001, the latest year for OECD data on social expenditures. We display results only for the instrumented version of each equation, since the choice between IV and single-equation estimates had no effect on the signs or general magnitudes of the institutional effects. ${ }^{\text {xxiii }}$

Of the dependent variables introduced in Table 1, we focus in this section on six key measures of job and output performance. ${ }^{\mathrm{xxiv}}$ We do not focus on the unemployment rate, which has dominated the labor-market literature. It has the drawback of giving equal weight to two labor transitions that are unequal in importance: the key transition between being employed and being inactive, and the transition between two inactive states, namely being in or out of the registered labor force. To focus on the first transition, and to link to the results on labor productivity, we follow the gross employment ratio for the 15-64 population. Later we look at unemployment rates for demographic subgroups. 
Control variables. Before turning to the featured institutional effects, we note that the control variables in Table 1 performed as expected. The strongest influence was the lagged dependent variable, whose coefficient was always between one-half and one. It should never be dropped from the equation, nor replaced with first differencing. A related dynamic variable is the catch-up variable, this country's income gap behind the United States ten years earlier. As expected, backwardness raised the growth rate of GDP per capita, but it had no clear effect employment or productivity levels.

The only non-performer among the control variables is educational attainment of the adult labor force. It proved insignificant in productivity and growth equations, probably because its gradual effect is eclipsed by the lagged dependent variable and the catch-up variable.

Having large shares of old or young population dragged down employment, productivity, and GDP growth, presumably because middle age groups are more productive.

Another strong set of control variables, the OECD-wide shocks to aggregate demand and aggregate supply, performed as expected. Strong demand raised jobs, productivity, output, and the growth rate, and bad supply shocks (here meaning the oil shocks) cut jobs, productivity, output, and growth.

The results for institutions and budgetary policies are illustrated with test statistics on some very large institutional increments in Table $2 .^{\mathrm{xxv}}$

Product market regulations. While European governments have retained most of their job protection, unemployment compensation, and high taxes, they have been steadily dismantling their product market regulations since 1980. In fact, all 21 core OECD countries have followed this path. The top row in Table 2 suggests that this movement boosted output per employed person or per labor hour everywhere, possibly by large amounts. The average OECD country cut product market regulations by a little over two points (on a 0-6 scale) since 1980, which should have raised GDP per worker or per hour by more than one percent each initial three years, or by up to 10 percent over the whole sample period, once one reckons in the feedback through the lagged dependent variable. Plausible as this result may seem, we think the true unit effects of de-regulation in product markets may be both larger and smaller than our coefficients show. Larger, 
because the OECD measures of product market regulations cover only seven sectors (airlines, telecommunications, electricity, gas, post, rail, and road freight), missing the effects of deregulation in other sectors. Smaller, because other plausible specifications of the same equations do not show the strong significance of the product-regulation variable that is shown in Table 2. Deregulation probably did help growth throughout the OECD, but the evidence is not yet robust.

A related product-market institution, trade policy, did not show significant effects because it was not given a chance to do so in this era. Trade policy (not shown in Table 2) did not differ much over time or across these 21 countries since 1980.

Job Protection Laws (EPL). The debate over European jobs has devoted attention to the charge that EPL costs jobs and raises unemployment. Our estimates suggest a possible negative net effect on jobs, but one that could easily be zero. Our null result matches the conclusion on this issue by Nickell, Nunziata and Ochel (2005): "evidence that they [EPLs] have a decisive impact on overall rates of unemployment is mixed, at best." ${ }^{x x v i}$

As we hinted earlier, EPL has had clearer effects on productivity, especially with a 12-year lag. Interestingly, that effect depends on whether the country uses coordinated wage bargaining as an alternative job protection device. Table 2 presents two sets of results on EPL, one for countries with little or no wage coordination, and one for countries with closely coordinated wage setting. In the no-coordination context, increased job protection did not seem to reduce productivity. This may be because the extra job protection was implemented where protection was initially low, so that it protected a large number of relatively productive insiders while delaying the careers of very few outsiders, yielding positive net effects on productivity. Examples would be the American protections against collective dismissal under Reagan and Bush in 1988-1989, and similar modest initial increases in job protections in Canada 1984-1985 or Australia 1992-1993. By contrast, in contexts of strong wage coordination, extra EPL lowers productivity significantly. In these settings, EPL was older and the negative effects on productivity had time to appear. One example was Ireland in the decades after EPL was tightened in 1977-1978. Another was Spain after the end of the Franco era, in the dozen years when 
new power and security for insiders coincided with lingering coordination that in fact did little to moderate wages.

Coordination in wage bargaining. Even though OECD jobs studies played down the effects of coordinated wage setting, many econometric studies show that it had a positive effect on jobs. We get a similar positive result, with two significant changes: Coordination's positive effect seems to be on productivity rather than on jobs, and it appears to be strongest in economies where workers get relatively little protection from EPL. Thus coordination in wage bargaining affects our productivity and output growth results as strongly as it affected employment results in past studies. ${ }^{\text {xxvii }}$ Its positive role particularly fits the fuller and more secure employment achieved without strict EPL in the late 1990s in Ireland, and to a lesser extent in Austria, Denmark, and the Netherlands. ${ }^{\text {xxiii }}$

How can that be? While the sources of gains from coordination are not yet quantified, scholars have identified channels through which it could raise productivity over time. Coordination spawns wage moderation, which may tame sectoral rent-seeking and rent-sharing with job security. The consensus it builds can also cut the personnel costs of supervising workers. ${ }^{\text {xxix }}$ It may facilitate stable macro-policy by promoting trust. $^{\mathrm{xxx}}$

The favorable effects of coordination (presumably with wage moderation) are so strong that in combination with stricter EPL they significantly raise productivity. This would explain the "double jump" test statistics in the middle rows of Table 2. Again, the GDP gain seems to come mainly through productivity, suggesting the need for deeper research into how such institutional packages affect human capital formation over the longer run.

Unemployment compensation. To explore budget-related institutions, we must use the distinction between durable and transitory effects described above. Employment and productivity seem to react very differently to the durable and transitory components of unemployment compensation rules, taxes and transfers. The regressions confirmed this difference, which probably has two explanations. One is that optimizing employers and members of the labor force perceive the difference between durable and temporary changes in taxes and transfers. The other source is econometric: No amount of instrumenting seems to remove all short-run cyclical effects from tax and transfer shares 
of GDP. We therefore explore the durable influences of fiscal variables (the Xkd's), and omit transitory elements (Xkjt's) from the underlying equations. The durable effects can be represented by countries' sample averages of the relevant fiscal parameters, since these parameters tended to stay on a plateau in the 1978/1980-1999/2001 sample.

For this post-1980 period, the effects of more generous unemployment compensation tend to be negative, as expected. The slopes shown in Table 2 reveal that raising benefits reduces employment and overall GDP somewhat at the bottom and top of the range of benefit generosity experienced in the OECD. Starting with essentially zero benefits, as in Italy in 1979, the first introduction of unemployment compensation cuts GDP slightly. Then across the more typical middle ranges, with unemployment compensation at about 15 percent of median wage, offering more support to the unemployed has no clear effect. At the high end, such as the 31 percent support ratio offered in Belgium in 1982, more compensation reduces jobs and (probably) GDP. While the effects tend to be negative, they are not dramatically large. Probably the main reason for this is a simple point highlighted by the new estimates of the generosity of unemployment benefits: The benefits did not cause large drops in employment because those benefits were never greater than a third of a median wage for production workers.

Broader fiscal shifts. The effects of higher tax and transfer rates for the economy as a whole, in contrast, departed sharply from conventional wisdom. The "broader fiscal shift" rows of Table 2 show that higher tax and expenditure rates actually raised employment and output, whether the extra taxes were spent entirely on social transfers or on all kinds of expenditures in fixed proportions. The only exception is the negative effect on productivity per hour from raising taxes above 45 percent of GDP, as in Belgium in 1985.

As previous scholars have noted, this seldom-announced positive result should not seem strange, once one factors in both sides of the government budgets. ${ }^{\text {xxi }}$ Sustaining higher taxes and spending may not drag down growth in the context of the high-budget welfare states, which have some of the world's least corrupt governments. Since much of the extra public expenditure is spent on efficiency-building public health, public education and infrastructure, it outweighs the GDP costs of transfers like early-retirement subsidies or unemployment compensation. It also seems likely that some of the 
productivity gain comes from the stronger demand-smoothing effect of automatic stabilizers in the higher-budget countries.

Different effects for different worker groups. Many labor market institutions, particularly those that raise the costs of turnover, could affect the employment of different groups in diverse ways. The laws separating protected and unprotected workers could boost the pay and productivity of protected insiders at the expense of outsiders. In particular, many institutions benefit the jobs and pay of males over 25 at the expense of females and youth (here 15-24) in the labor force. The differential employment effects can be tested for ${ }^{\mathrm{xxxii}}$ by examining the the outsider/insider ratios of unemployment rates, with women and youth as the outsider groups. We choose unemployment rates rather than employment ratios because the employment ratio measures are complicated by school enrollment (especially for the young) and other influences on female labor force participation.

The clearest result, shown in Table 3, is that EPL strongly redistributes unemployment toward women and youth, to the advantage of males over 25 . As conjectured earlier, this insider/outside difference is one reason why the effects of EPL might be positive when it is first instituted, and negative later on. When first implemented, EPL protects a large share of the labor force and may do no net damage to on-the-job skill formation. With the passage of time, however, a rising share of workers spends a longer time queuing for protected jobs, causing a net drop in human capital. Table 3 supports this story: where EPL is stricter, outsiders have higher unemployment rates.

Other institutions have mixed effects on female and youth unemployment. A country with strict product market regulations seems to discourage female employment and help youth, for unknown reasons. Closer wage coordination has the opposite tendency. The combination of strong EPL and wage coordination still shifts unemployment to outsiders, so that the discriminatory effect of EPL outweighs the more equal treatment implied by wage coordination. Table 3 seems to show that more generous unemployment compensation favors employment of outsiders, but the result should be read through its male denominator: Unemployment compensation allows more males over 25 to be officially unemployed. Finally, raising taxes in general seems to shift 
unemployment toward youth, perhaps because social security taxes raise the cost of an initial hire.

If the insider-outsider effect of EPL is so strong, it should show up in the raw data, and not just in multivariate regressions. It does, both in the broad movements over time and in the differences across countries. It was in the 1970s that unemployment became dramatically higher for youth and women, relative to men. This timing correlates with the rise in EPL, and the shift toward unemployed women and youth was stronger in the high-EPL Mediterranean and Belgium than elsewhere. Today's international pattern shows the likely link to EPL even more clearly. Table 4 contrasts the loci of unemployment in highly protective Italy and Greece with the pattern in less protective Ireland and Denmark. The unemployment-rate ratios tilt more strongly toward the young and women in the two high-EPL Mediterranean countries, in a way that was much less true before the rise in Mediterranean EPL. The strongest conclusion so far is that employee protection laws clearly redistribute jobs toward males over 25 at the expense of others.

\section{B. Some Suspects Not Featured Here, and Why Not}

Not all institutions can be analyzed here, for varying reasons. The closest near miss is the mix of tax types within the over tax bill. We did test for differences in jobs and productivity caused by shifts among three tax categories: consumption taxes, social security payroll deductions, and income plus property taxes. We did not find robust results, however, so that any hunches about the merits of consumption taxation must remain hunches. ${ }^{\text {xxiii }}$

Despite a determined effort to include the effects of active labor market policies (ALMPs), we have still been unable to pin down their effects from such a panel. The basic reason is that we could not reliably separate ALMP policies from the cyclically sensitive outlays associated with them. We note the optimism about such activist policies in the recent literature, but cannot confirm or reject it here. ${ }^{\text {xxiv }}$

Some other leading suspects escape trial for want of sufficient data. So it was with minimum wage laws, early retirement subsidies, the productivity revolution in retailing, and research and development policies. 


\section{Those Vexed Fixed Effects (UFOs)}

Institutional results for all studies of European employment are strongly affected by the inclusion or exclusion of conventional time or country fixed effects. The usual practice is to hide these effects behind rows that simply indicate whether unidentified fixed effects are included. We feel this is a mistake in settings where the real influences are durable rather than transitory, as in the recent history of jobs and growth in the OECD. Recall from Equation (3) above that the durable behaviors can be linear combinations of the coefficients of those binaries by time and place, posing a tough problem of interpretation. A researcher must decide: Do I select linear combinations of binary fixed effects that capture durable forces at work in the economy (the Xkd's) or do I use the standard approach, adding J-1 fixed place effects and T-1 fixed time effects to the regression?

In the name of reserving judgment, economists have chosen the latter path, and have thrown away information. The usual fixed-effects interpretation reveals a belief in mysterious UFOs (unidentified fixed objects), which are presented as though they were forces known to be separate from the X's. But what are they? Is there no hope of finding what lies behind them? We press this issue with Table 5 and Figure 3.

Table 5 shows that the UFOs so often used but so seldom displayed in other studies correlate strongly with the country-average components of some variables but not others. For our 1978-2001 sample, country fixed effects correlate strongly and positively with big government (the total tax share) in all job, productivity, and growth equations. One can even run regressions with the country UFOs as a dependent variable explained by the tax share and a few other Xkd's, and get suggestive. Doing so is a big first step toward endogenizing the UFOs. Experimenting with such regressions in fact gives us back the main conclusions featured in connection with Table $2 .^{\mathrm{xxxv}}$

Figure 3 dramatizes the same point by comparing the fixed country effects for the $\log$ of GDP per person with the share of all taxes in GDP. The usual way of presenting fixed-effect binaries implies that something unexplained about Sweden and Japan made Sweden's GDP per person 56\% higher than Japan's, other things equal; yet the usual presentation invites us to think that this $56 \%$ advantage is unrelated to Sweden's high 
taxes or welfare transfers, which already entered the same regression equation. Sweden's UFO also pushes Sweden's GDP per person 39\% above that of the United States, which tends to be a favorable outlier in the international spectrum.

How should people interpret such striking patterns? Attributing them to separate "unobservable" forces seems inadequate. We recommend viewing such patterns as revealing information that researchers should have featured all along: The durable effects of institutional packages are often captured in the fixed effects, and are quite different from the transitory coefficients that economists pursue and announce. Focusing on the durable effects corresponds with the kind of question that motivated our research: What would happen if an institution were durably changed, and not reversed the next year?

We interpret the differences caused by fixed binary effects as follows:

(1) The correct provisional results are those already presented in Table 2, without conventional binary fixed effects.

(2) Adding the conventional UFOs yields fixed-place coefficients that mix true unobservables with large doses of durable effects from such variables as the welfare state high-tax nexus. So the correlations of Table 5 and figure 3 suggest. Their positive effects for welfare states partly reflect the productivity-raising features of the welfare state, such as more efficient health care and support for mothers' careers. ${ }^{\text {xxxvi }}$

(3) Offsetting these positive effects of the larger-budget, larger-transfer nexus are equally negative coefficients for transitory effects of extra taxes and (especially) transfers, in the underlying fixed-effect regressions. We interpret these negative transitory effects as showing the effect of nation-specific and time-specific cyclical macro-shocks, which could not be distilled out in any clear way. In other words, what some studies found to be negative effects of taxes-minus-transfers on growth are due to positive effects in the reverse direction.

Thus researchers using panel data face a hard choice between conventional binary fixed effects (UFOs) and selecting only those fixed effects that are durable behavioral influences, such as a country's long-lasting labor laws. Which choice is correct depends on the historical setting. Most panel studies assume that the durable and transitory forms 
of behavior have the same slope, so that the UFOs represent only separate forces that deserve to be kept out of the limelight. If the researchers are lucky, that assumption will be true. Yet the task of judging institutions in OECD countries is not such a case. The fixed effects probably reflect durable influences of the variables already entered into the equation. Only a broader and more eclectic weighing of the evidence allows us to decide.

\section{A Deeper History: How the 1960s-1970s Were Different}

Institutional influences on employment and growth appear to evolve over time, and we have begun to suggest some reasons why. To track this evolution, we compare the results summarized above with those from a similar panel for 19 countries over six three-year periods, 1963/1965-1978/1980. ${ }^{\text {xxvii }}$

For this earlier period, like the recent one just summarized, control variables explained most of the temporal changes in employment and productivity. The shocks to aggregate demand and supply, especially the oil shocks, account for much of the change from 1973 on. Lagged dependent variables and age variables also played the same strong roles as in the later era.

The institutional effects, however, seem to have been evolving. The contrasts between Table 6's test statistics for the 1960s-1970s are quite different from those we reviewed for the later era in Table $2 .^{\text {xxxviii }}$

Before 1980, employee protection laws did not seem to have the negative effects they have delivered since 1980. Whether stricter EPL had a positive effect depended on whether the tightening occurred in a context of coordinated wage bargaining. Without coordinated settlements, tighter EPL may have had no clear effects within this time period. With coordination, tightening EPL seems to have had positive effects on jobs and GDP over the 1960s and 1970s, even though it eventually dragged down productivity, as shown in Table 2 above. Combining strict EPL with coordinated wage-setting worked well in Scandinavia in these early years.

We tentatively interpret EPL's effects over time in terms of the insider-outsider model and the career cycle. In the 1960s-1970s, EPL was new in most of Western Europe, except on the Iberian peninsula. It protected a large share of workers and initially 
denied work to relatively few outsiders, so the job effect was positive during cyclical shocks, and productivity was not yet compromised. As the century wore on, however, the outsider share of the labor force kept growing. The favorable job effect and the net

effect on human capital were overwhelmed by the negative effects on outsiders' careers, yielding the negative effects in Tables 2 and 3.

On the fiscal front, the 1960s-1970s results differ from the fiscal effects in the post-1980 era. Raising unemployment compensation from zero to low levels promoted jobs and productivity in the way predicted by the Sinn (1995) model. General fiscal expansion, on the other hand, had negative effects in the bottom and top budget ranges, while its effect on the heavily represented middle range could have any sign. We offer no explanation why raising taxes and spending had a negative effect on results for the 1960s1970s, yet lacked any clear negative effect in other plausible specifications for these same decades or for the period after $1980 .^{\text {xxxix }}$

\section{A Wider World: Evidence beyond the OECD}

To avoid passing up relevant information, the debate over Europe's jobs and growth should look beyond the OECD to other countries where restrictive labor laws are in place. Although Europe's high transfers are not matched elsewhere, costly dismissals for senior workers or high minimum wages are also found in Latin America, Southern Africa and India. The spirit of the new comparative economic history calls on the OECD debate to consider this wider evidence, which, as in Europe, spans all of the economist's usual micro- and macro-tests.

For Latin America and the Caribbean, institutions that make labor markets less flexible seem to have reduced formal-sector employment and output, as in Western Europe since about 1980. The institutions are not always as focused on preventing layoffs as in Europe, but they are similar enough to offer strong suggestions for the European debate. Latin American and Caribbean experience, like the OECD over the last quarter century, shows that EPL has lowered formal sector employment, mainly for women and youths. ${ }^{\mathrm{xl}}$ 
Chilean experience offers a particularly good laboratory for testing the effects of changes in labor laws, thanks to annual surveys of Santiago spanning four decades that included sharp reversals in labor market policy. The costs of dismissal were sharply raised in 1966, slashed by Pinochet in 1974, and raised in 1985 and 1991. Real minimum wages stagnated in relation to average wages over last four decades of the 20th century, except in the mid-1970s, when the minimum/average ratio was raised sharply (average wages were held down while the minimum rose, an un-Chicago result). Surveys of about 300,000 workers in Santiago showed that tightening job security raised employment for prime working-aged males and reduced employment for women and youths, as in the OECD experience. ${ }^{\text {xli }}$

A study of responses to two increases in Brazil's dismissal costs confirms that job tenure for youths and women declined relative to males aged 25 and older. Gonzaga (2003) used about 500,000 job records from six cities between 1982 and 2002, when the costs of dismissing workers rose twice (the1988 Constitution and a September 2001 law), within the context of a complicated government-run severance fund system. A differences-in-differences analysis shows that men over 25 gained in job tenure relative to women and youths, even though the net effect on total jobs is unclear. ${ }^{\text {xlii }}$

For India and Southern Africa, the effects are more broadly negative, even when measured as contemporaneous net effects on employment and productivity. Besley and Burgess (2004) trace the effects of 28 changes in India's labor market institutions, most of which involved raising the cost of layoffs. These changes reduced jobs, output and productivity, and raised poverty. ${ }^{\text {xiii }}$ Labor market restrictions similarly seem to account for much of Zimbabwe's unemployment since independence. ${ }^{\text {xliv }}$

\section{Two Kinds of Verdicts}

This paper demonstrates how eclecticism in pursuing evidence pays off by delivering clearer verdicts than a narrower empirical exercise might have yielded. Our wider range of tests brings us to two different kinds of verdicts, familiar from American trial law: reasonable-doubt verdicts and preponderance-of-evidence verdicts. 
The reasonable-doubt rule, as practiced in American criminal cases, makes it harder to rule against a defendant (here, institutions). If some evidence doesn't fit, we must acquit. Robustness is one econometric translation of the reasonable-doubt yardstick. Only one of our conclusions delivers this demanding a verdict against any of Europe's debated labor-market or fiscal institutions. This verdict is that employee protection laws have created labor-market insiders and outsiders as portrayed by Lindbeck and Snower (2001), ${ }^{\mathrm{xlv}}$ reducing employment and earning power for women and youths relative to males over 25 .

However, our eclectic body of evidence has yielded several preponderance-ofevidence verdicts. ${ }^{x l v i}$ The preponderance of evidence suggests that the effects of employee protection laws on employment and GDP have become less positive and more negative over time. When first instituted, EPL can boost employment without compromising productivity, as in the 1960s-1970s era. Over time, however, the employment gain evaporates as outsiders become a rising share of the labor force. At the same time, negative productivity effects creep in, as a declining share of the whole work force's career history is spent as protected insiders. Product market regulations also appear guilty of lowering productivity, though the evidence against them still leaves reasonable doubts. By the 1980s-1990s unemployment compensation had also drifted toward the negative effect predicted by theory.

Other institutions are acquitted, even on the preponderance of evidence criterion. Coordinated wage setting seems to have very positive job and productivity effects. And the overall bundle of welfare state transfers shows no negative effects on either jobs or output, at least not since 1980. 


\section{BIBLIOGRAPHY}

Addison, John T. and Paulino Teixeira. 2003. "The Economics of Employment Protection." Journal of Labor Research 24, 1 (Winter): 85-129.

Agell, J. 1999. "On the Benefits from Rigid Labour Markets: Norms, Market Failures, and Social Insurance.” Economic Journal 108: 143-164.

Allard, Gayle. 2003. "Jobs and Labor Market Institutions in the OECD.” Doctoral dissertation, University of California - Davis.

Allard, Gayle J. 2005. "Jobs and Labor-Market Institutions in the OECD: A New Look at the Dynamics." Working Paper, Instituto de Empresa, Madrid.

Atkinson, A.B. 1999. The Economic Consequences of Rolling Back the Welfare State. Cambridge: MIT Press.

Auer, Peter. 2000. Employment Revival in Europe: Labour Market Success in Austria, Denmark, Ireland, and the Netherlands. Geneva: ILO.

Baker, Dean, Andrew Glyn, David Howell, and John Schmitt. 2005. "Labor Market Institutions and Unemployment: A Critical Assessment of the Cross-Country Evidence.” In David Howell (ed.), Fighting Unemployment. Oxford: Oxford University Press, pp. 72-118.

Bassanini, A., S. Scarpetta, and P. Hemmings. 2001. "Economic Growth: The Role of Policies and Institutions: Panel evidence from OECD Countries.” Economics Working Departmental Paper, no. 283, OECD.

Bean, Charles. 1994. "European Unemployment: A Survey,” Journal of Economic Literature, 32, 2 (June): 573-619.

Bertola, Giuseppe, Francine D. Blau, and Lawrence M. Kahn. 2001. "Comparative Analysis of Labor Market Outcomes: Lessons for the US from International Long-Run Evidence.” NBER Working Paper 8526, October 2001, and in Alan B. Krueger and Robert Solow (eds.), The Roaring Nineties: Can Full Employment Be Sustained? New York: Russell Sage Foundation 2001.

Bertola, Giuseppe, Francine D. Blau, and Lawrence M. Kahn. 2005. "Labor Market Institutions and Demographic Employment Patterns", European University Institute, January. 
Besley, Timothy and Robin Burgess. 2004. "Can Labor Regulation Hinder Economic Performance? Evidence from India." Quarterly Journal of Economics 119, 1 (February): 91-134.

Blanchard, Olivier. 2004. "Explaining European Unemployment.” Written for NBER Reporter, April 5, 2004.

Blanchard, Olivier. 2004. "The Economic Future of Europe." Journal of Economic Perspectives 18, 4 (Fall): 3-26.

Blanchard, Olivier and Justin Wolfers. 2000. "Shocks and Institutions in the Rise of European Unemployment: The Aggregate Evidence,” Economic Journal 110, 462 (March): C1-C33; and "Data and Appendix." http://econwp.mit.edu/RePEc/2000/blanchar/harry_data/.

Bruno, Michael and Jeffrey. 1985. The Economics of Worldwide Stagflation. Cambridge MA: Harvard University Press.

Calmfors, Lars and J. Driffil. 1988. "Centralisation of Wage Bargaining, Corporatism, \& Macroeconomic Performance." Economic Policy 6.

Elmeskov, J., J. Martin, and Stefano Scarpetta. 1998. "Key Lessons for Labor Market Reforms: Evidence from OECD Countries Experience." Swedish Economic Policy Review 5 2: 205-252.

Fallon, Peter R. and Robert E.B. 1991. “The Impact of Changes in Job Security Regulations in India and Zimbabwe." World Bank Economic Review 5, 3: 395-413.

Flanagan, Robert J. 1988. "Unemployment as a Hiring Problem.” OECD Economic Studies 11 (Autumn): 123-154.

Flanagan, Robert J. 1999. "Macroeconomic Performance and Collective Bargaining: An International Perspective.” Journal of Economic Literature 37, 3 (September): 11501175.

Freeman, Richard B. 1998. "Single-Peaked vs. Diversified Capitalism: The Relation between Economic Institutions and Outcomes.” NBER Working Paper 7556.

Freeman, Richard B. 2005. "Labour Market Institutions without Blinders: The Debate over Flexibility and Labour Market Performance.” NBER Working Paper 11286 (April).

Freeman, Richard B. and James L. Medoff. 1984. What Do Unions Do? New York: Basic Books. 
Freeman, Richard B. and Ronald Schettkat. 2005. "Marketization of Production and the US-Europe Employment Gap.” Economic Policy 20, 41 (January): 6-50.

Gonzaga, Gustavo. 2003. "Labor Turnover and Labor Legislation in Brazil.” Economía 4, 1 (Fall): 165-207.

Gordon, D. 1994. "Bosses of Different Stripes: A Cross-National Perspective on Monitoring and Supervision." American Economic Review 84, 2 (May): 375-379.

Gordon, Robert J. 2004. "Why Was Europe Left at the Station when America's Productivity Locomotive Departed?” NBER Working Paper 10661 (August).

Gordon, Robert J. and Ian Dew-Becker. 2005. "Why Did Europe's Productivity Catch • up Sputter Out? A Tale of Tigers and Tortoises.” San Francisco Federal Reserve Bank, November.

Gordon, Robert J. Forthcoming. "Comparing Welfare in Europe and the United States." In a Berkeley-Vienna volume edited by Barry Eichengreen.

Heckman, James, and Carmen Pagés (eds.). 2004. Law and Employment: Lessons from Latin America and the Caribbean. National Bureau of Economic Research Conference Report, University of Chicago Press.

Helms, L. Jay. 1985. “The Effects of State and Local Taxes on Economic Growth: A Time Series Cross Section Approach.” Review of Economics and Statistics 67, 4 (November): 574-582.

Kneller, Richard, Michael Bleaney, and Norman Gemmell. 1999. "Fiscal Policy and Growth: Evidence from OECD Countries." Journal of Public Economics 74, 2 (November): 171-190.

Lazear, Edward P. 1990. “Job Security Provisions and Employment.” Quarterly Journal of Economics 105: 699-726.

Lindbeck, Assar and Dennis J. Snower. 2001. "Insiders versus Outsiders.” Journal of Economic Perspectives 15, 1 (Winter): 165-188.

Lindert, Peter H. 2004. Growing Public: Social Spending and Economic Growth since the Eighteenth Century. Two volumes. Cambridge: Cambridge University Press. Montenegro, Claudio E. and Carmen Pagés. 2004. "Who Benefits from Labor Market Regulations? Chile, 1960-1998.” In Heckman, James, and Carmen Pagés (eds.), 
Law and Employment: Lessons from Latin America and the Caribbean. Chicago: University of Chicago Press, pp. 401-434.

Nickell, Stephen J. 1997. "Unemployment and Labor Market Rigidities: Europe versus North America." Journal of Economic Perspectives 11, 3 (summer): 55-74.

Nickell, Stephen J. 2004. "Employment and Taxes." CEP Discussion Paper No 634 (May).

Nickell, S. J. and Layard, R. 1999. "Labour Market Institutions and Economic Performance" in O. Ashenfelter and D. Card (eds.) Handbook of Labor Economics, Vol 3 (Amsterdam: North Holland).

Nickell, Stephen J., Luca Nunziata, and Wolfgang Ochel. 2005. "Unemployment in the OECD since the 1960s: What do We Know?" Economic Journal 115 (500): 01-27.

Ochel, Wolfgang. 2000. "Collective Bargaining (Centralization/Coordination).” Munich: Ifo Institute.

Organisation for Economic Cooperation and Development (OECD). 1985. Social Expenditure 1960-1990. Paris: OECD.

OECD. 1994. The OECD Jobs Study: Evidence and Explanations. Two volumes. Paris: OECD.

Polachek, S.W. and W.S. Siebert. 1993. The Economics of Earnings. New York: Cambridge University Press.

Sala-i-Martin, Xavier. 1997. "I Just Ran Two Million Regressions.” American Economic Review 87, 2 (May): 178-183.

Scarpetta, Stefano. 1996. "Assessing the Role of Labour Market Policies and Institutional Settings on Unemployment: A Cross-Country Study." OECD Economic Studies 26, 1: 43-98.

Schneider, Friedrich and Robert Klinglmair. 2004. "Shadow Economies around the World: What Do We Know?" CESifo Working Paper No. 1167 (April).

Siebert, Horst. 1997. "Labor Market Rigidities: At the Root of Unemployment in Europe." Journal of Economic Perspectives 11, 3 (summer): 37-54.

Sinn, Hans-Werner. 1995. "A Theory of the Welfare State.” Scandinavian Journal of Economics 97, 4: 495-526.

Sinn, Hans-Werner. 1996. "Social Insurance, Incentives, and Risk Taking." International Tax and Public Finance 3, 3 (July): 259-280. 
Teulings, Coen and Joop Hartog. 1998. Corporatism or Competition? Labour Contracts, Institutions and Wage Structures in International Comparison. Cambridge: Cambridge University Press. 


\section{CAPTIONS FOR FIGURES}

Figure 1. Unemployment Compensation, 1950-2000

Figure 2. Employee Protection Laws, 1950-2000

Figure 3. UFOs and Taxes: One Pattern Explaining Unidentified Fixed Country Effects

(UFOs) for GDP per Person in the OECD, 1978-

2001

Figure 1. Unemployment Compensation 1960 - 2003

Panel A. Core EU Countries

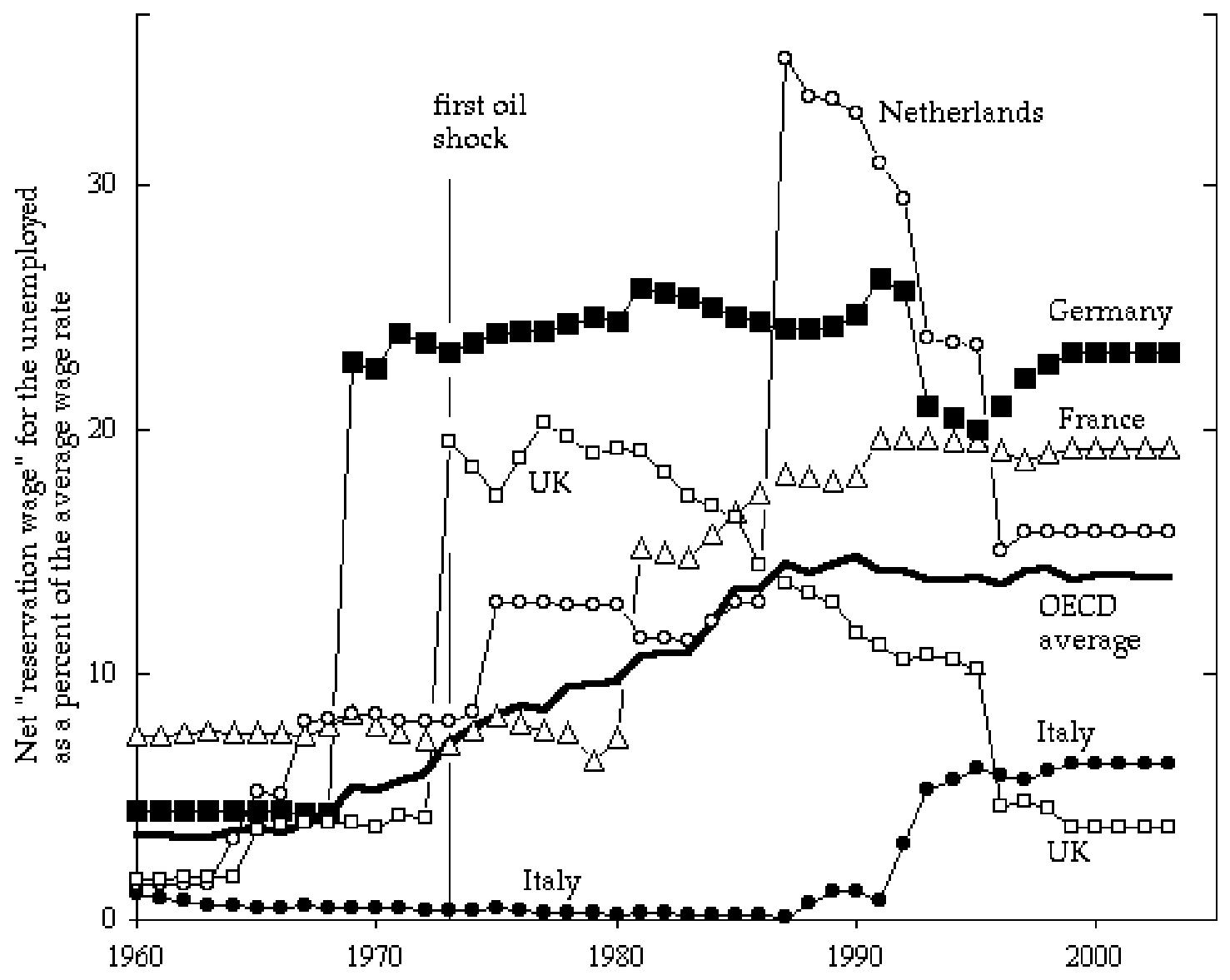

Source: Allard (2003). 
Figure 1, Panel B. The Outer World

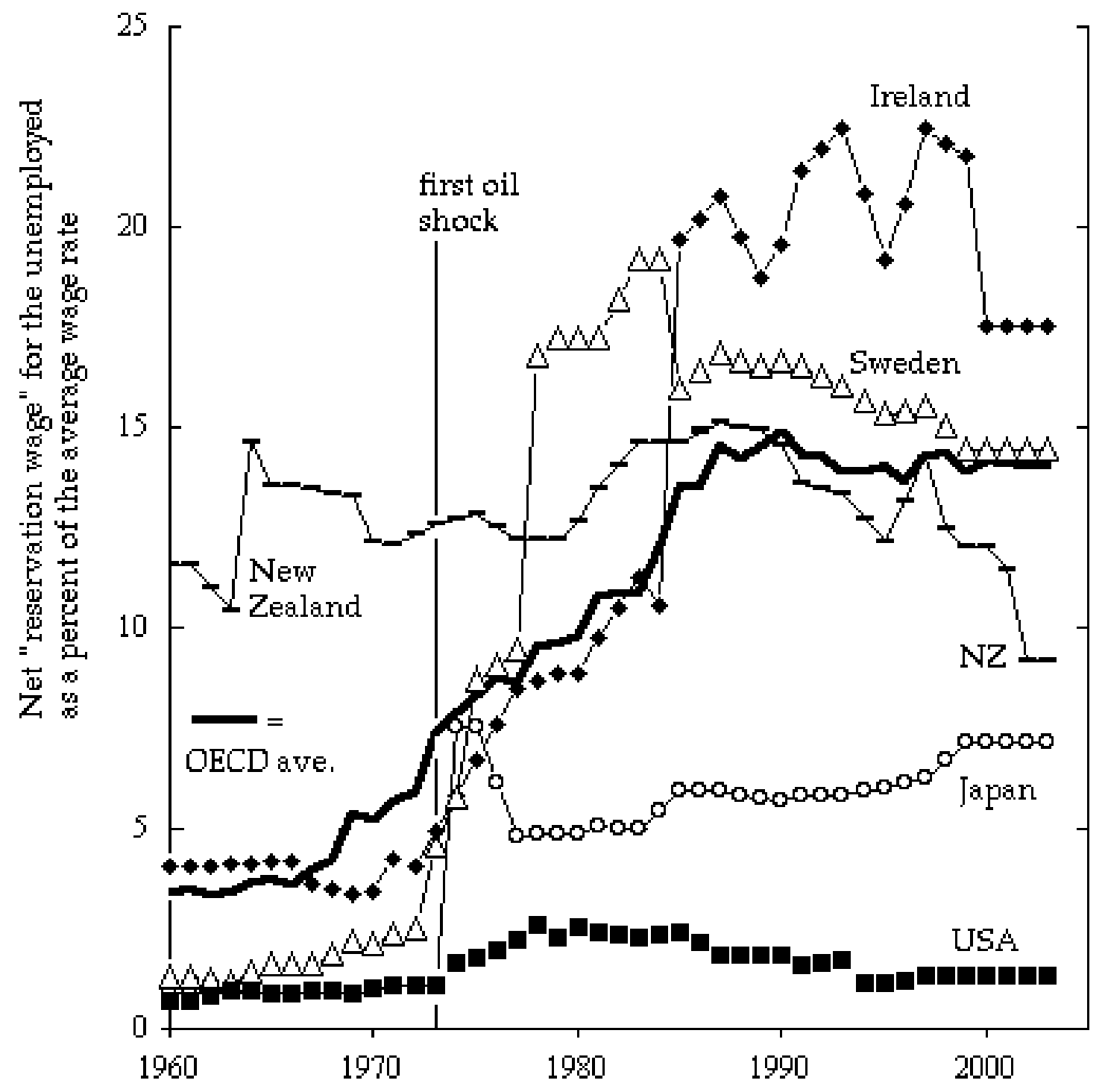

Allard-Lindert, Page 33 
Figure 2. Employment Protection Laws 1960 - 2003

Panel A. Core EU Countries

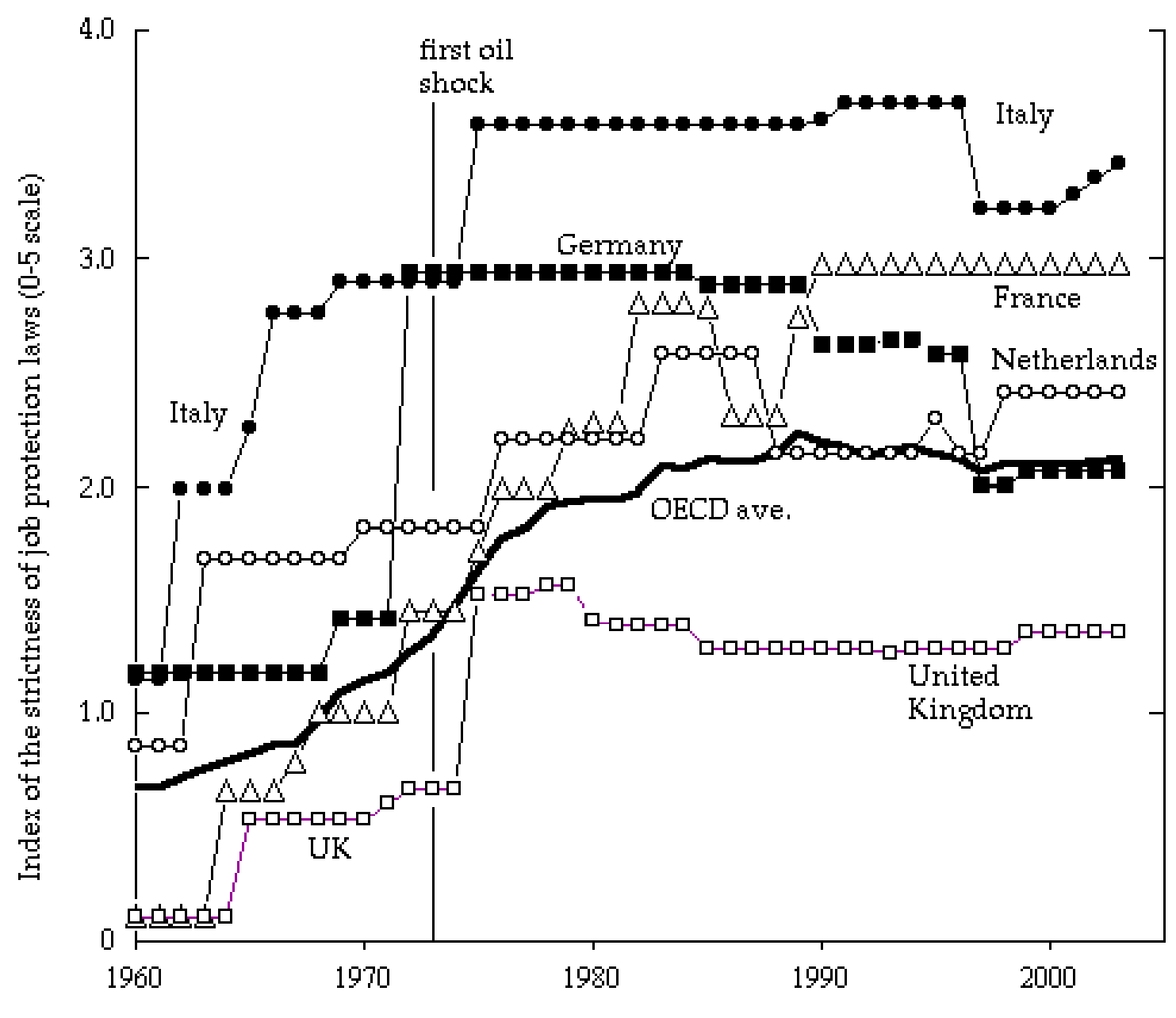

Source: Allard (2003). 
Figure 2, Panel B. The Outer World

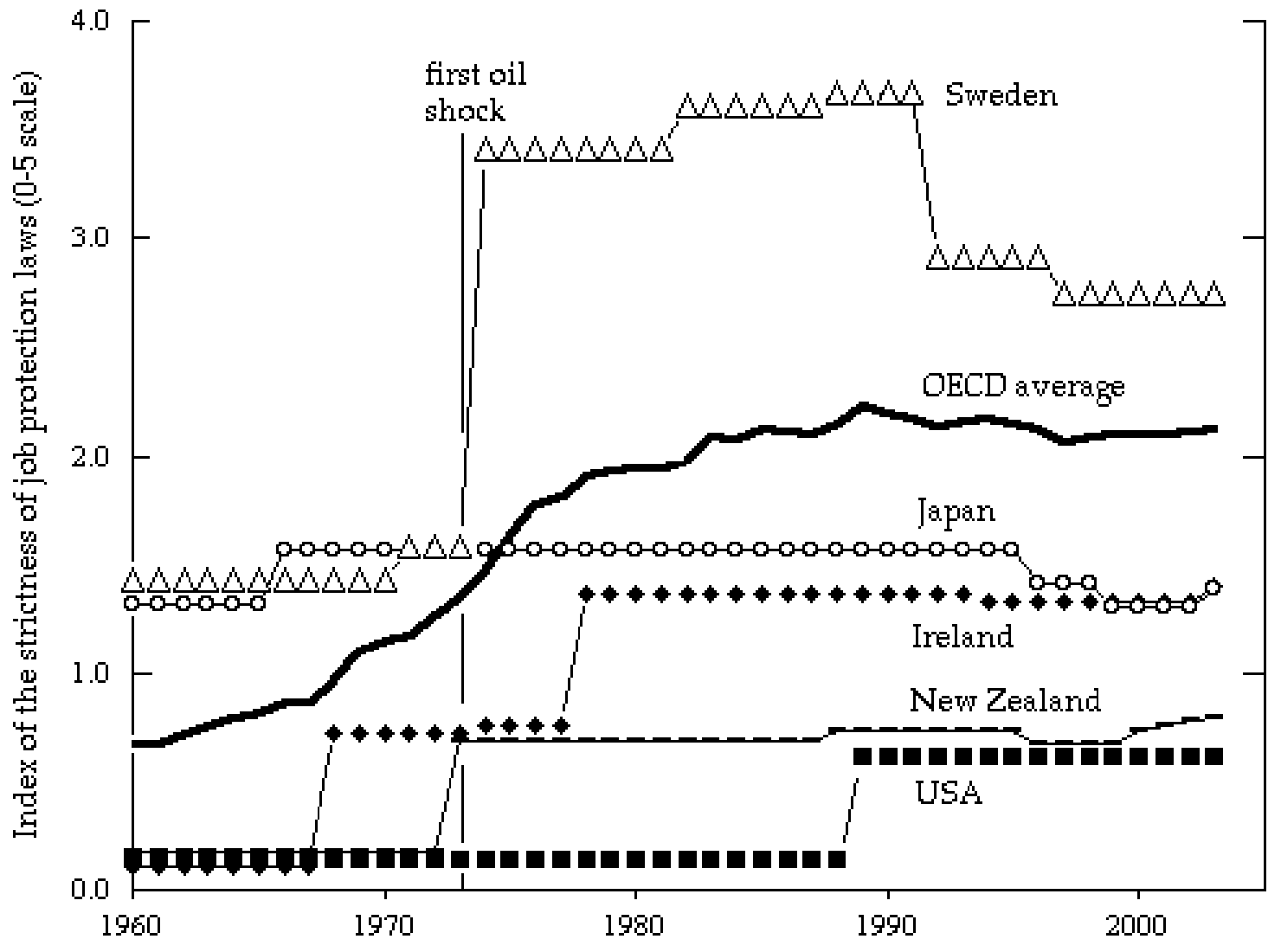

Allard-Lindert, Page 35 
Figure 3. UFOs and Taxes: One Pattern in the Unexplained Fixed Country Effects (UFOs) for GDP per Person in the OECD, 1978 - 2001

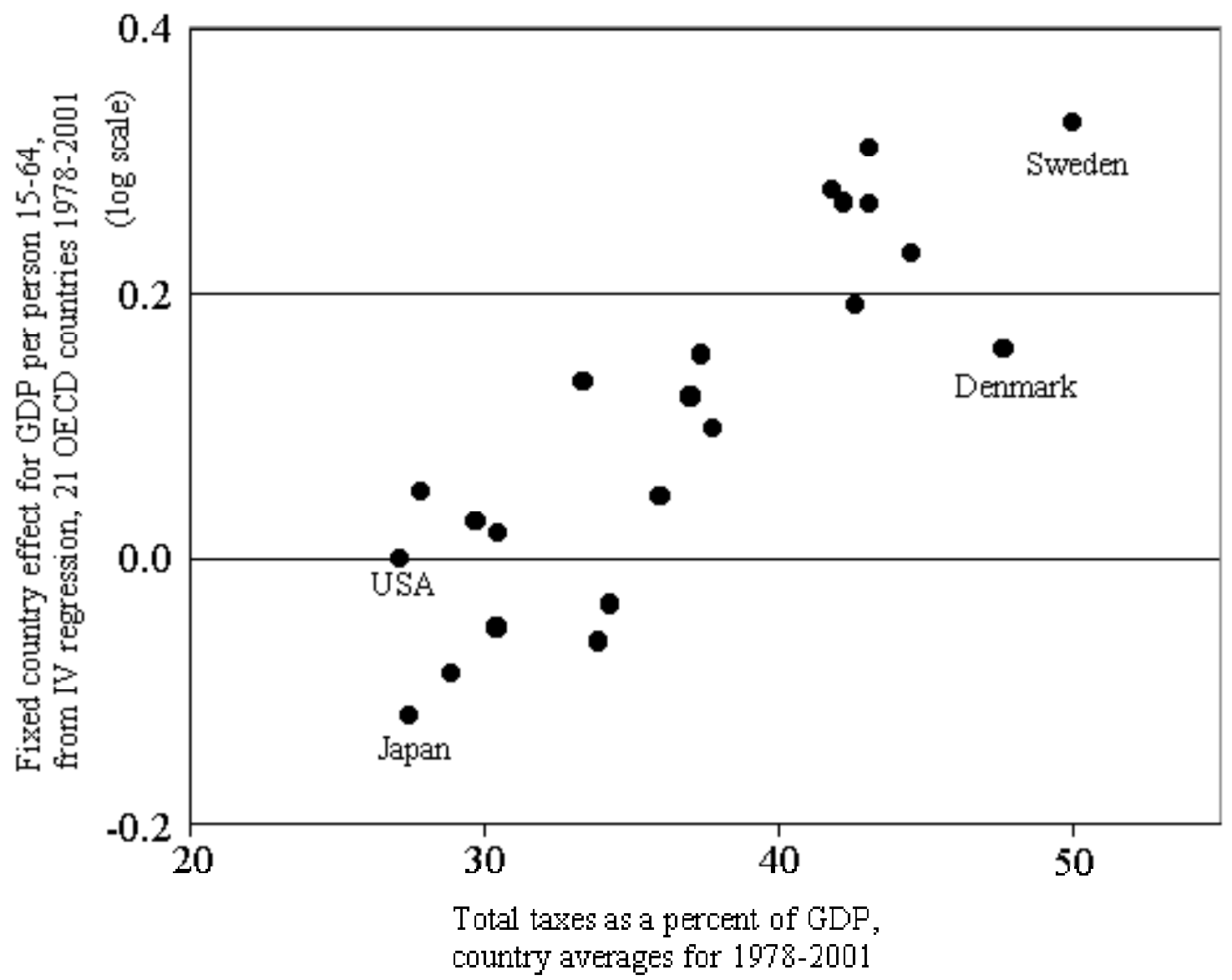

Allard-Lindert, Page 36 


\section{ENDNOTES}

i Gordon 2004, Gordon and Dew-Becker 2005, Gordon forthcoming.

ii Bruno and Sachs 1985 captured the best thinking on these issues in the mid-1980s, by blending macroshocks and labor-supply institutions into a plausible explanation of comparative stagflation.

iii For two surveys of the earlier literature, see Bean 1994 and Nickell and Layard 1999.

iv OECD 1994, Scarpetta 1996, Nickell 1997, Siebert 1997, Elmsekov et al. 1998, Flanagan 1999,

Bassanini et al. 2001, Nickell 2004, Nickell et al. 2005.

v From Baker et al. 2005. See also Freeman 2005.

vi Blanchard and Wolfers 2000.

vii Heckman and Pagés 2004, p. 2.

viii To survey the growth literature, see Bassanini et al. 2001; Blanchard, "Future," 2004; Gordon 2004; and Gordon and Dew-Becker 2005.

ix Kneller et al. 1999 emphasize that growth equations that estimate the impacts of either taxes alone or expenditures alone yield "biased" estimates, because they omit the other side of the budgetary balance. Our own estimates do take account of both sides, yet we note that their term "biased" is perhaps too ominous. The previous one-side-of-the-budget literature was not statistically biased. The tax-alone and expenditure-alone estimates can give unbiased answers to different questions, of the form "what if we changed only one budget category, and financed the change with the mixture of offsetting items actually used in practice?" Such questions are natural and practical, so that the one-sided approach also serves a useful purpose.

Not all of our results, here or in Lindert 2004, Chs. 18, 19, agree with those of Kneller et al. Differences between their approach and ours include: they do not try non-linear effects, they instrument only by using lagged variables, and they do not explore the full range of institutions and time periods explored here.

${ }^{x}$ GDP and productivity here refer to the formal economy, and exclude the shadow economy. Thus the effects on formal jobs and GDP of institutions that raise the shadow-economy share of employment or output will be understated in this and other studies. According to the literature estimating the shadow economy, taxes on employment have this effect (see the studies cited in Schneider and Klinglmair 2004). Therefore payroll and similar taxes should have a more positive effect on true jobs and output than the usual econometric estimates will show. This and past studies may similarly understate the positive job and productivity effects of EPL and unemployment compensation, a point implicit in Freeman and Schettkat 2001.

xi For a laudable exception, exploring the effects on labor groups by age and sex, see Bertola, Blau, and Kahn 2005. 
xii A classic statement is Freeman and Medoff 1984.

xiii Polachek and Siebert 1993, 82-83, 155-164.

xiv Sinn 1995, 1996, Agell 1999.

xv Blanchard and Wolfers, 2000, p.C2. Similarly, Blanchard, "Explaining," 2004, p. 3: "European labor market institutions did not come into being in the early 1970s. For the most part, both the architecture and the level of social protection were put in place earlier, and were then consistent with low unemployment." xvi Nickell, Nunziata, and Ochel 2005, p. 4.

xvii Allard 2003, 2005.

xviii These measures are based on rules and statutes. At times observed expenditure behavior shows different movements from what the rules imply at face value.

xix Before these new estimates based on Allard 2003 and 2005, the historically deepest set of estimates was that of Lazear 1990.

xx Ochel 2000.

xxi To capture these two shocks, we used four variables rather than two. The first two are the (inflation unemployment) and (inflation + unemployment) shocks for the whole OECD, multiplied by the individual country's trade openness (exports plus imports divided by GDP). The other two are the same thing multiplied by a dummy for the United States. This reflects the fact that the United States carries a considerably greater weight than any other country in the OECD-wide averages for inflation and unemployment.

xxii Calmfors and Driffil 1988. A similar idea is presented by Freeman 1998.

xxiii For the first-stage instrruments used in the IV variant, see Appendix A.

xxiv To focus on the most meaningful conclusions about institutional impacts, Tables 2, 3, and 6 present results based primarily on test statistics for linear combinations of coefficients, rather than on single coefficients. For a few of the original regressions from the 1978/1980-1999/2001 sample, see Appendix B. xxv We caution that Tables 2, 3, and 6 will display very large increments in institutions and budgetary policies for rhetorical purposes. Such jumps never actually occurred from one three-year period to the next, even though all the institutional combinations actually occurred in the sample. The counterfactuals shown in these tables violate the "speed limit" for counterfactuals described in Lindert 2004, vol. 2, pp. 29-30. xxvi Nickell, Nunziata, and Ochel 2005, p. 10. For a similar conclusion, see Addison and Teixeira 2001. xxvii Baker et al. 2005, and the studies cited there.

xxviii Auer 2000.

xxix Gordon 1994, Teulings and Hartog 1998.

xxx Auer 2000; Blanchard "Explaining," 2004. 
xxxi See, for example, Helms 1985, Atkinson 1999, and Lindert 2004, Chapters 10 and 18. Kneller et al. 1999 results agreed with this statement regarding higher taxes spent on government purchases, but not regarding higher taxes for transfer spending.

xxxii See, in particular, Bertola, Blau, and Kahn 2001 and 2005. Some of their tests trace the effects of unionization rather than the institutions emphasized here, but unionization rates and these institutions are sufficiently correlated to make the results comparable.

xxxiii Clearer results were announced by Kneller et al. 1999, as noted earlier. Yet we prefer our regression specification, and could not confirm their results with our chosen equations.

xxxiv Nickell, Nunziata, and Ochel (2005, p. 6) are relatively upbeat about ALMP's ability to cut unemployment, citing macro-studies by Scarpetta 1996, Nickell, 1997, and Elmeskov et al., 1998, and the microeconometric studies summarized in Martin 2000.

${ }^{x \times x v}$ We have done so in unreported regressions on the 22 fixed country effects ( 21 countries minus the base country, but with different effects for Germany before and after 1990). The same UFO regressions should have more power when there are more fixed place effects, as in inter-state regression analyses of the fifty United States.

xxxvi For fuller evidence on these effects, see Lindert 2004, especially Chapter 10.

xxxvii The 19 countries are those listed in the notes to Table 2, minus Portugal and Spain, for whom we lack data on social transfers. The earlier sample also lacks the OECD index of product-market regulations.

xxxviii The differences in structure make it unwise to combine the whole 1963-2001 era into a single sample, unless one can cleverly specify equations that capture the structural evolution.

xxxix For alternative specifications over both historical samples, see Lindert 2004, Volume 2, Appendix E.

${ }^{x l}$ See the studies in Heckman and Pagés 2004.

xli Montenegro and Pagés 2004.

xlii Gonzaga 2003. In Brazil's case, the rise in dismissal costs lowered turnover within a policy system that generated fake layoffs and a labor turnover rate as high as any in the world. It is therefore possible that by reducing Brazil's turnover rate, the 1988 Constitution and the 2001 law raised the productivity of privileged insiders enough to outweigh the productivity losses to outsiders, who had high turnover in any case. Our text here emphasizes the clearer point: Raising dismissal costs favored men's jobs over jobs for women and youths.

xliii Besley and Burgess 2004.

xliv Fallon and Lucas 1991.

xlv Lindbeck and Snower 2001.

xlvi The econometric analogy to a preponderance of evidence verdict is Xavier Sala-i-Martin's acceptance of confidence interval verdicts from repeated trials instead of stricter interpretations of "robustness." (Salai-Martin 1997). 


\section{Table 1. Sets of Second-Stage Equations to Explain Employment, Unemployment, Productivity, and Growth in the OECD, 1963-2001}

Job outcomes

Employment ratio, 15-64 population

Employment ratio, 15-64 women

Unemployment rate, overall

Unemployment rate, women/men

Unemployment rate, youth/men

Productivity and GDP outcomes

In (GDP per person employed)

ln (GDP per labor hour)

ln (GDP per person 15-64)

$\ln$ (GDP per capita)

3-year log growth rate, GDP per capita

Basic control variables

Dependent variable, lagged 3 years

ln(GDP per cap./US GDP per cap.), 10 yr. lag

Educational attainments of adults

Young (0-15 share)

Old (share 65 and up)

Global demand shocks (OECD infl. - unem.)

Global supply shocks (OECD infl. + unem.)

Institutional forces

Product-market regulations in seven sectors

Internationally open policies (Freedom House)

Employee protection laws (EPL)

12 years ago

Change from 12 years ago to 6 years ago

Change from 6 years ago to current

12 years ago, interacted with levels of coord.

Coordinated wage-setting is intermediate

Coordinated wage-setting is strong

Budgetary policies

Unemployment comp. (\& squared \& cubed)

Total taxes/GDP ( \& squared \& cubed)

Income \& property tax share of total taxes

Consumption tax share of total taxes

Social transfer share of total taxes

Fixed-country binaries**

Fixed-time binaries

$\begin{array}{ccc}\begin{array}{c}\text { Main } \\ \text { equations }\end{array} & \begin{array}{c}\text { Growth } \\ \text { equations }\end{array} & \begin{array}{c}\text { Results } \\ \text { displayed? }\end{array}\end{array}$

Dep

Dep

Dep

Dep

Dep

Dep

Dep

Dep

Dep

Dep

Tables 2, 5

Table 3

Table 3

Tables 2, 5

Tables 2, 5

Tables 2, 5

Tables 2, 5

$\mathrm{X}^{*}$

$\mathrm{X}$

$\mathrm{X}$

$\mathrm{X}$

$\mathrm{X}$

$\mathrm{X}$

$\mathrm{X}$

X

$\mathrm{X}$

$\mathrm{X}$

$\mathrm{X}$

X \& IV

$\mathrm{X}$

$\mathrm{X}$

$\mathrm{X}$

X \& IV

$X$ \& IV

$X \& I V$

$X \& I V$

$\mathrm{X} \& \mathrm{IV}$

X \& IV

(IVs in Tables 2, 5)

$X \& I V$

(IVs in Tables 2, 5)

$X \& I V$

(IVs in Tables 2, 5)

$X \& I V$

(IVs in Tables 2, 5)

$X \& I V$

(IVs in Tables 2, 5)

Table 4

Notes to Table 1: 
* = For the female and youth rates of employment and unemployment, the lagged "dependent" variable is the lagged overall rate, not the rate specific to women or youth.

** For Germany, there are two different binary-variable "fixed countries":

West Germany up through 1989, then all Germany from 1990 on.

Dep $=\quad$ Dependent variable, to be explained in one of this set of equations.

$\mathrm{X}=\quad$ An exogenous variable used in all variations of this equation.

IV $\quad$ A predicted value based on instruments in a first-stage OLS equation.

$\mathrm{s}=\quad$ An exogenous variable used in some variants of this equation, not others.

The sample is a balanced panel of 21 OECD countries times three-year time periods.

The 21 countries are Australia, Austria, Belgium, Canada, Denmark, Finland, France,

Germany (West to 1989, all Germany 1990 on), Greece, Ireland, Italy, Japan, Netherlands, New Zealand, Norway, Portugal, Spain, Sweden, Switzerland, the United Kingdom, and USA. However, Spain and Portugal were omitted from the pre-1980 sample, for want of OECD measures of social transfer spending.

The three-year time periods are 1978/80-1999/2001 (so that $\mathrm{n}=21 * 8$ periods $=168$ ), $1963 / 1965-1978 / 1980$ (so that $\mathrm{n}=19 * 6$ periods $=114$ ), and in some non-displayed variants, the whole period 1963/1965-1999/2001 $(\mathrm{n}=19 * 13=247)$.

Employment ratio $=$ employment divided by the $15-64$ population .

$\mathrm{EPL}=$ an index (0-5) of the strictness of employee protection laws, updated from (Allard 2003).

Coordinated wage setting $=$ an index from 1 to 3, from Ochel 2000, with 1999 values extended through 2001. An intermediate level of wage coordination was any Ochel rating between 2.0 and 2.5, inclusively. A strong level of wage coordination was any case with the rating $=3.0$. (There were no cases between 2.5 and 3.0.)

For a sketch of the first-stage equations generating the predicted values from instruments, see Appendix A. These refer only to the Instrumental Variable (IV) variants, of course.

For data sources, see (Allard 2003) and the Excel table "OECD annual 1950-2001," forthcoming on our internet sites. 
Table 2. The Three-Year Effects of Selected Institutional Changes on Jobs and GDP, 1978-2001

\begin{tabular}{|c|c|c|c|c|c|}
\hline \multirow{3}{*}{ Institutional changes (independent variables) } & \multicolumn{5}{|c|}{ The percentage estimated effects on -- } \\
\hline & & GDP per & GDP per & GDP per & 3 -year growth rate \\
\hline & $\underline{\text { Jobs }}$ & worker & hour & person $15-64$ & of GDP per capita \\
\hline \multicolumn{6}{|l|}{$\overline{\text { Market regulations -- }}$} \\
\hline \multirow[t]{2}{*}{ Raising the index of product-market regulation } & -0.06 & $-1.23 * *$ & $-1.13 * *$ & $-2.16 * *$ & 0.30 \\
\hline & \#\#\#\# & $(0.45)$ & $(0.36)$ & $(0.74)$ & $(0.40)$ \\
\hline
\end{tabular}

Tightening employee protection laws (EPLs), by 1 index point for 12 years or more
(a) with little or no wage-setting coordinatio -0.66
1.70 a $\quad 1.66 * *$
$-1.26$
0.51
(b) with close coordination in wage-setting -0.52
$(0.90)$
$(0.67)$
$(1.42)$
$(0.91)$
\#\#\#
$-6.06 * * \quad-3.50 * *$
(1.50) (1.13)
$-5.16 * \quad-3.66 * *$
(2.49) (1.45)

Shifting the index of coordinated wage-setting from no wage coordination to high
(a) with weak EPLs
2.92
$22.62 * * \quad 15.31 * *$
$20.64 * * \quad 14.70 * *$
(b) with strict EPLs
\#\#\#\#
(3.09)
(2.79)
(4.92)
(2.83)
3.39
$-4.14$
$-1.87$
6.47
0.59
\#\#\#\#
(2.76)
(1.75)
(4.78)
(2.78)
$\begin{array}{cc}5.59 & * 6.18 * * \\ (2.54) & (1.76)\end{array}$
5.14
$4.70 \mathrm{~b}$
EPL and from no wage coordination to high \#\#\#\#
(4.09)
(2.60)

\section{Fiscal wedges in the labor market --}

Raising the unemployment compens. support ratio

- from $0 \%$ (e.g. Italy 1979) to $1 \%$

$-0.20$

\#\#\#\#

$$
-0.39 \text { a }
$$

$-0.05$

$-0.82 *$

$-0.18$

- from $15 \%$ (e.g. France 1982) to $16 \%$

$$
0.04
$$

$(0.22)$

$(0.19)$

$(0.34)$

(0.22)

\#\#\#\#

$(0.08)$

$0.12 \mathrm{~b}$

$-0.10$

0.03

- from $30 \%$ (e.g. Belgium 1982) to $31 \%$

$\begin{array}{lr}-0.25 * & -0.10 \\ \# \# \#+\frac{10}{2} & (0.16)\end{array}$

(0.06)

(0.12)

(0.07)

\#\#\#\#

(0.16)

0.19

$-0.28$

$-0.15$

$(0.22)$

(0.14) 


\section{Table 2, continued}

The percentage estimated effects on --

\section{Broader fiscal shifts --}

GDP per GDP per GDP per 3-year growth rate

Raising all taxes and transfers in proportion

- taxes up from $27 \%$ of GDP (USA) to $28 \% \quad 0.13$

\#\#\#\#

- taxes up from $35 \%$ of GDP (Italy 1985) to -0.01

\#\#\#\#

- taxes up from 45\% of GDP (Belgium 19850.20

\#\#\#\#

Raising taxes and spending them only on extra transfers

- taxes up from $27 \%$ of GDP (USA) to $28 \% \quad 0.17$

\#\#\#\#

- taxes up from $35 \%$ of GDP (Italy 1985) to 0.03

\#\#\#\#

- taxes up from 45\% of GDP (Belgium 19850.22

\#\#\#\#

worker

$\underline{\text { hour }}$

$\begin{array}{cccc}0.35 \mathrm{~b} & -0.16 & 0.36 & 0.62 \text { ** } \\ (0.20) & (0.16) & (0.33) & (0.21) \\ 0.33 * * & 0.37 * * & 0.29 \mathrm{~b} & 0.09 \\ (0.10) & (0.08) & (0.16) & (0.11) \\ -0.10 & -0.44 * * & 0.61 * & 0.06 \\ (0.15) & (0.10) & (0.27) & (0.15)\end{array}$

$0.37 \quad-0.20$
$-0.25)$

$\begin{array}{rr}(0.25) & (0.20) \\ 0.34 * & 0.33 *\end{array}$

$(0.17) \quad(0.13)$

$-0.09$

$-0.46 * *$

(0.17)

(0.12)

$\begin{array}{cr}0.56 & 0.57 * \\ (0.41) & (0.26) \\ 0.44 \text { b } & 0.05 \\ (0.25) & (0.18) \\ 0.71 * & 0.04 \\ (0.30) & (0.17)\end{array}$

Coefficient on the lagged dependent variable\#

$\begin{array}{cccc}0.98 \text { ** } & 0.86 * * & 0.89 * * & 0.76 \text { ** } \\ \# \# \# \# & (0.02) & (0.02) & (0.04)\end{array}$


Notes and sources to Table 2:

(Standard errors in parentheses. $* *=$ significant at the $1 \%$ level (two-tail). $*=$ significant at the $5 \%$ level. $\mathrm{a}=$ significant at the $7 \%$ level; $\mathrm{b}=$ significant at the $10 \%$ level.)

\# To compute eventual steady-state impacts, multiply the (logged) 3-year coefficients by $1 /(1$ - this coefficient).

For the structures of the equations, see the sketch in Table 1 and the details in the Appendices.

"Jobs" here $=$ the ratio of employed persons to the adult population of working age (15-64).

Min, mean, max of its natural $\log =-0.78,-0.43,-0.16$.

Productivity per worker $=$ real GDP per employed person. Min, mean, max of its natural $\log =9.9,10.57,11.1$.

Productivity per hour = GDP per labor hour. Min, mean, $\max$ of its natural $\log =9.9,10.55,11.0$.

Product market regulation $=$ an index of the degree of regulatory intervention in product markets.

Min, mean, $\max =1.00,4.1455,5.98$.

The index of strictness of employment protection laws (EPLs) ranges from 0 to 5. See Allard (2003).

Min, mean, $\max =0.10,2.09,3.83$. Here "weak" EPLs = an index of 0.4 (USA), and "strict" = an index of 3.5 (Italy).

The index of collective wage setting ranges from 1 to 3 , and is from Ocher (2000). Min, mean, $\max =1.0,1.98,3.0$.

Here "little or no coordination" $=1$ and "close coordination" $=3$.

The overall generosity and use of compensation to the unemployed is the Allard "net reservation wage."

More specifically, it is measured as the product of

(a) the marginal "replacement rate," or (benefits per recipient) divided by (market wage), net of taxes;

(b) the coverage rate, the share of unemployed persons who are eligible; and

(c) the duration of coverage over the first year.

Welfare-state social transfers as a share of GDP include public pensions, public health, unemployment compensation, family assistance, and public housing. Min, mean, $\max =7.64 \%, 20.50 \%, 32.80 \%$.

The variants shown here exclude non-human capital formation from the set of regressors, implicitly endogenizing capital formation and the capital stock.

The equation for GDP per person 15-64 is estimated directly, not derived from the by the employment and productivity estimates shown in the earlier columns.

All equations displayed here have highly significant $\mathrm{F}$ statistics. 
Table 3. The Three-Year Effects of Selected Institutional Changes On the Relative Unemployment of Women and Young Adults, 1978-2001

The estimated effects on --

Female/ male unemployment, among those 15-64

Youth (15-24) unemployment /

Institutional changes (independent variables) unemployment among males 15-64

Market regulations --

$0.065(0.024) * * \quad \# \# \# \quad(0.05) * *$

Tightening employee protection laws (EPLs), by 1 index point for 12 years or more
(a) with little or no wage-setting coordination
$0.197(0.052) * *$
$0.482(0.10) * *$
(b) with close coordination in wage-setting
$0.288(0.101) * *$
$0.420 \quad(0.13) * *$

Shifting the index of coordinated wage-setting from no wage coordination to high
(a) with weak EPLs
\#\#\#\# (0.232)*
$0.085 \quad(0.28)$
(b) with strict EPLs
\#\#\#\# (0.124) a
\#\#\#\# (0.22) b
The double jump, both from low (0.4) to high (3.5) $0.282 \quad(0.148)$ a
$1.328 \quad(0.30) * *$ EPL and from no wage coordination to high (from 1.0 to 3.0 )

\section{Fiscal wedges in the labor market --}

Raising the unemployment compensation support ratio

- from $0 \%$ (e.g. Italy 1979) to $1 \%$

- from $15 \%$ (e.g. France 1982) to $16 \%$

- from $30 \%$ (e.g. Belgium 1982) to $31 \%$
\#\#\#\# (0.016) **

\#\#\#\# $(0.006) *$

$0.015(0.012)$
\#\#\#\# $\quad(0.03) * *$

\#\#\#\# $\quad(0.01) * *$

\#\#\#\# (0.04)** 
Table 3, continued

\section{Broader fiscal shifts --}

Raising all taxes and transfers in proportion

- taxes up from $27 \%$ of GDP (USA) to $28 \%$

- taxes up from 35\% of GDP (Italy 1985) to $36 \%$

- taxes up from $45 \%$ of GDP (Belgium 1985) to 46 ${ }^{c}$ \#\#\#\#

\#\#\#\# (0.008) b

$(0.010) *$

Raising taxes and spending them only on extra transfers

- from $27 \%$ of GDP (USA) to $28 \%$

- from $35 \%$ of GDP (Italy 1985) to $36 \%$

$0.033 \quad(0.018)$

\#\#\#\# (0.011)

- from $45 \%$ of GDP (Belgium 1985) to $46 \%$
Youth (15-24) unemployment /

unemployment among males 15-64

Coefficient on the lagged ln(employ't ratio), 15-64s $\quad \# \# \# \# \quad(0.238) * * \quad$ \#\#\#\# $\quad(0.37) * *$

Notes and sources to Table 3:

(Standard errors in parentheses. $* *=$ significant at the $1 \%$ level (two-tail). $*=$ significant at the $5 \%$ level. $\mathrm{a}=$ significant at the $7 \%$ level; $\mathrm{b}=$ significant at the $10 \%$ level.)

The female/male ratio of unemployment rates in the 15-64 age range has a 21 -country (min, average, $\max )=(0.57,1.35,2.88)$.

The youth/men unemployment ratio has sample (min, average, $\max )=(1.1,2.31,5.4)$. Its sample consists of 14 countries:

Australia, Canada, Finland, France, Germany, Ireland, Italy, Japan, Netherlands, Norway, Portugal, Spain, Sweden, USA. For the structures of the equations, see the sketch in Table 1 and the details in the Appendix.

The other notes to Table 2 also apply here. 
Table 4. Employee Protection Laws Redistribute Unemployment toward Outsiders: Four Countries in 2002

\begin{tabular}{|c|c|c|c|}
\hline & & Ratios of un & ent rates \\
\hline & $\begin{array}{l}\text { EPL } \\
\text { strictness }\end{array}$ & $\begin{array}{l}\text { Youth 15-24 } \\
\text { /men 25-64 }\end{array}$ & $\begin{array}{l}\text { Women 25-64 } \\
\text { /men 25-64 }\end{array}$ \\
\hline Greece & 3.8 & 4.2 & 2.4 \\
\hline Italy & 3.3 & 3.8 & 1.8 \\
\hline & & & \\
\hline Ireland & 1.3 & 1.7 & 0.8 \\
\hline Denmark & 1.6 & 1.6 & 1.2 \\
\hline
\end{tabular}

Source: SourceOECD, standardized unemployment rates. 


\section{Table 5. What's Hiding Inside the Conventional Unidentified Fixed-Country Effects (UFOs) for 1978-2001?}

Correlations of these regression-based fixed country effects ...

... with 1978-2001 averages by country for these variables

\section{Market regulations}

Product market regulations

EPL strictness now

EPL strictness 12 years ago

Wage-setting coordination (Ochel)

Overall budget variables

Total taxes / GDP (see Fig. 3)

Income and property tax / all taxes

Consumption taxes / all taxes

Social transfers / total taxes

Labor-specific budget variables

The "tax wedge" on labor earnings

Generosity of unemployment compensat

ALMP support ratio

Other conditioning variables

Educational attainment, in years

Shadow economy / GDP in 1989

$$
\begin{aligned}
& \ln \text { (employ- } \ln \text { (GDP per } \ln \text { (GDP per } \quad \ln \text { (GDP per } \quad \text { log-growth } \\
& \underline{\text { ment ratio) }} \text { employed) labor hour) person 15-64) of GDP/capita }
\end{aligned}
$$

$\begin{array}{rrrrr}-0.16 & 0.47 & -0.03 & 0.24 & 0.34 \\ 0.11 & 0.50 & -0.05 & 0.44 & 0.43 \\ 0.17 & 0.44 & 0.00 & 0.42 & 0.39 \\ \mathbf{0 . 4 1} & 0.42 & 0.41 & 0.48 & 0.52 \\ & & & & \\ \mathbf{0 . 6 7} & \mathbf{0 . 6 3} & \mathbf{0 . 6 6} & \mathbf{0 . 8 6} & \mathbf{0 . 6 8} \\ -0.11 & \mathbf{- 0 . 7 0} & -0.08 & -0.54 & \mathbf{- 0 . 5 7} \\ -0.27 & 0.21 & 0.19 & 0.04 & -0.06 \\ 0.38 & 0.50 & 0.30 & 0.53 & 0.55 \\ & & & & \\ 0.43 & \mathbf{0 . 7 7} & \mathbf{0 . 4 7} & \mathbf{0 . 8 0} & \mathbf{0 . 7 2} \\ 0.36 & 0.30 & \mathbf{0 . 5 6} & 0.41 & 0.39 \\ \mathbf{0 . 8 0} & 0.16 & 0.20 & \mathbf{0 . 5 5} & 0.37 \\ & & & & \\ 0.33 & -0.47 & 0.10 & -0.11 & -0.41 \\ -0.29 & 0.22 & -0.13 & 0.07 & -0.02\end{array}$

Notes:

Boldface $=$ The column's top three correlations (in absolute value) .

The fixed country effects for each column come from regressions described in connection with Tables 1 and 2 . While these came from the instrumented equations, those from uninstrumented equations give similar results.

There are 22 fixed country effects. These are for the 21 countries (USA $=0$ ), but with German averages split into two countries: West German averages for 1978-1989, and all-German averages for 1990-2001. 


\section{Table 6. The Three-Year Effects of Selected Institutional Changes on Jobs and GDP, 1963-1980}

\begin{tabular}{|c|c|c|c|c|}
\hline & The percentage estil & tted effect & & 3-year growth \\
\hline Institutional changes (independent variables) & $\begin{array}{r}\text { GDP per } \\
\text { worker }\end{array}$ & $\begin{array}{r}\text { GDP per } \\
\text { hour }\end{array}$ & $\begin{array}{l}\text { GDP per } \\
\text { person } 15-64\end{array}$ & $\begin{array}{l}\text { rate of GDP } \\
\text { per capita }\end{array}$ \\
\hline
\end{tabular}

Tightening employee protection laws (EPLs), by 1 index point for 12 years or more
(a) with little or no wage-setting coordinatio -2.25
2.30
$-1.58$
1.03
$-0.64$
(1.45) (1.51)
$(1.32)$
$(2.33)$
$(1.57)$
(b) with close coordination in wage-setting
(1.13) (1.24)
(1.17)
$4.89 * * \quad 2.46 \mathrm{a}$
(1.85) (1.34)

Shifting the index of coordinated wage-setting from no wage coordination to high
(a) with weak EPLs
$\begin{array}{lll}-0.02 & 0.55 & 1.03\end{array}$
$-0.13$
$-1.03$
(b) with strict EPLs
(1.61) (2.09)
(2.10)
(2.78)
(2.18)
$(3.78) \quad(4.28)$
$7.02 \mathrm{~b}$
$12.17 \mathrm{a}$
8.89 a
6.44
$4.28)$
3.16
(4.15)
(6.12)
(4.52)
The double jump, both from low (0.4) to high (
$(3.04)$
1.07
$12.98 * * \quad 4.91$
EPL and from no wage coordination to high (3.13)
(2.74)
(4.58)
(3.30)

\section{Fiscal wedges in the labor market --}

Raising the unemployment compens. support ratio

- from $0 \%$ (e g Switzerland, Italy 1973) to 10.82

$\begin{array}{rrrrr}0.82 * & 0.99 * & 1.06 * & 1.99 * * & 0.58 \\ (0.40) & (0.49) & (0.43) & (0.64) & (0.50) \\ -0.13 & 0.07 & -0.05 & 0.16 & 0.29 \mathrm{~b} \\ (0.15) & (0.15) & (0.15) & (0.21) & (0.16) \\ 0.16 & 0.02 & -0.27 & 0.01 & -0.24 \\ (0.21) & (0.23) & (0.18) & (0.29) & (0.24)\end{array}$

- from $10 \%$ (e.g. Denmark 1973) to $11 \%$

$-0$.

0.07

$-0.05$

0.16

$0.29 \mathrm{~b}$

- from $20 \%$ (e.g. Belgium 1973) to $21 \%$

0.16

$(0.23)$

$-0.27$

0.01

(0.24) 


\section{Table 2, continued}

\section{Broader fiscal shifts --}

Raising all taxes and transfers in proportion

- taxes up from 22\% of GDP (Japan 1973) tr -0.04

- taxes up from 30\% of GDP (Belgium $1964-0.26 *$

$$
\begin{array}{cccc}
-0.98 * * & -1.15 * * & -1.09 * * & -1.29 * * \\
(0.25) & (0.21) & (0.36) & (0.27) \\
-0.17 & -0.10 & -0.53 * & 0.03 \\
(0.16) & (0.15) & (0.21) & (0.17) \\
-0.66 * & -0.59 * & -1.34 * * & -0.84 * \\
(0.30) & (0.29) & (0.47) & (0.34)
\end{array}
$$

(0.11)

- taxes up from $40 \%$ of GDP (Austria 1979) - 0.26

$(0.26)$

Raising taxes and spending them only on extra transfers

- taxes up from $22 \%$ of GDP to $23 \%$

$-0.23 \quad-0.71 *$

(0.27)

$(0.30)$

- taxes up from $30 \%$ of GDP to $31 \%$

$-0.37 *$

$-0.01$

$-0.60 *$

-0.86 a $\quad-1.13 * *$

(0.16)

(0.23)

(0.25)

$(0.44)$

(0.33)

$-0.33$

$-0.57 \mathrm{a}$

0.22

$-0.40$

0.12

- taxes up from $40 \%$ of GDP to $41 \%$

$(0.26)$

(0.30)

$-0.40$

$(0.30)$

$(0.24)$

$-1.25 * * \quad-0.78 *$

(0.46) (3.35)

$\begin{array}{lllll}\text { Coefficient on the lagged dependent variable\# } & 0.86 * * & 0.96 * * & 0.95 * * & 0.90 * * \\ (0.04) & (0.03) & (0.02) & (0.05)\end{array}$

Notes and sources to Table 6:

(Standard errors in parentheses. $* *=$ significant at the $1 \%$ level (two-tail). $*=$ significant at the $5 \%$ level. $\mathrm{a}=$ significant at the $7 \%$ level; $\mathrm{b}=$ significant at the $10 \%$ level.)

For the structures of the equations, see the sketch in Table 1 and the details in the Appendix.

The other notes to Table 2 also apply here. 


\section{APPENDIX A. The First-Stage Equations Used in the Instrumental-Variable Variants}

For the instrumented-variable variants of the second-stage equations featured in Tables 2, 3, 5, and 6, we chose first-stage instruments in a two-part procedure designed to exclude groups of instruments that failed to add significant power to the first-stage prediction of the potentially endogenous institutional and fiscal variables.

First, we gave the broadest possible set of independent variables suggested by theory, and began pruning insignificant sets of instruments. Of the variables that survived this pruning process, some overlap with the second-stage regressors. This is generally undesirable, yet such variables were kept in the set of instruments here on the grounds that they really did affect some of the endogenous institutional variables.

The second part of the first-stage was the actual OLS estimation based on the narrower set of instruments that survived the pruning process. The predicted values from these estimates were used in the IV variants of the second stage.

As a possible alternative for purging cyclical effects from the endogenous fiscal variables, we also experimented with extracting a cyclical component tied to unemployment and inflation, in the spirit of many authors' calculations of fullemployment budget surpluses. This failed to make any difference to the estimates. Whichever variant was tried, there was still a cyclical and transitory component of the budget variables (taxes and transfers), which behaved quite differently from the more permanent component. As explained in the text, separating these two helps the equations to answer the basic question about the effects of sustained institutional shifts.

In the first part, or first regression pass, of the first-stage estimation, we used an over-broad set of regressions to predict the following potentially endogenous institutional and policy variables: (1) EPL strictness; (2) the "net reservation wage" offered to the unemployed; (3) the degree of wage coordination; (4) the active labor market policy (ALMP) support ratio, which equals (unemployment benefits per unemployed) / (GDP per person in the labor force); (5) the country's openness to international transactions, measured by Freedom House's Index 4; (6) income and property taxes as a share of GDP; 
(7) social security contributions from payroll, as a share of GDP; (8) taxes on goods and services as a share of GDP; (9) social transfers as a share of GDP; (10) total taxes as a share of GDP; and (11) the tax wedge on labor earnings.

The over-broad set of potential instruments included:

(a) a binary variable for a politically conservative regime;

(b) the share of adults who voted in the last general election, and itself squared and cubed;

(c) military spending as a share of GDP;

(d) membership in a customs union or free trade area;

(e) share of public sector in employment;

(f) $\log$ of national population in millions;

(g) share of population that is younger than 15, and the same share squared and cubed;

(h) share of population that is 65 or older, and the same share squared and cubed;

(i) primary and secondary school enrollment rate ten years earlier;

(j) university enrollment rate 10 years earlier;

(k) employee protection law strictness lagged 9 years, and its changes of the subsequent 6 years;

(j) the lagged "net reservation wage" (Allard 2003) received after taxes by the average unemployed nine years earlier, and its changes of the subsequent 6 years;

(k) an index of centralized wage bargaining, and its lagged values of the preceding nine years;

(l) dummies for each three-year time period (except the last period in the sample); and

(m) dummies for each country except for the United States. An exception: Separate dummy variables were used for West Germany before 1991 and for unified Germany thereafter.

Next came the pruning process, to exclude groups of variables that did not prove significant in the initial regressions run on this over-broad list of potential instruments. In all equations, the binary variable for politically conservative regime added no explanatory power and was pruned altogether. Here is an equation-by-equation listing of other variables that got pruned from the first-stage equations:

Equation (1), predicting EPL strictness - The strictness of employee protection laws was driven largely by its own earlier values. It was practically an exogenous variable subject to a random walk. Still, to explore what difference it would make to endogenize EPL, we ran an equation to predict EPL without these variables: the military spending share of GDP, the public-sector employment share, membership in a customs union or free trade area, the child share, the old share, the fixed-time dummies, and the levels of wage coordination.

Equation (2), predicting the net reservation wage, our measure of the generosity of offers of unemployment compensation - We dropped the military spending share, the publicsector job share, membership in a customs union or free trade area, lagged school enrollments, lagged university enrollments, and the log of total population. 
Eq. (3), income and property tax as a share of GDP: Most instruments played a significant role. The only ones dropped were the military share, the public sector's share of employment, and the school enrollment ratio.

Equation (4) for commodity taxation as a share of GDP, we dropped military spending, the public sector share of employment, log of total population, the child (0-15) share of the population, and the lagged net reservation wage.

Equation (5), social transfers as a share of GDP -- We dropped the log of population and the wage coordination variables. The voting share was a strong determinant of social transfers, here as in Lindert (2004).

Equation (6) Total taxes as a share of GDP - In this case, we dropped the military share, the lagged school enrollment rate, the child (0-15) share, the elderly (over 65) share, and the lagged rates of unemployment compensation.

Equation (7) The OECD's publicized tax wedge as a share of labor earnings - This was unavailable for early years. For the later sample, it usually showed negative influences on jobs and productivity, as one would expect. For this study, it has been dropped in favor of the larger total-tax aggregate that includes it.

We omitted any equation predicting either wage coordination (linear version of the index) or the binaries indicating whether the index was in the intermediate or high coordination class. The wage coordination variables were left exogenous, since no instruments other than fixed country effects predicted them well.

In the case of the active labor market policy (ALMP) support ratio, this whole variable had to be omitted from the second stage, even though we have data on it for most countries after 1980. Trying to include it, either with or without instrumenting, yielded fragile and often implausible results. The underlying problem is that the cyclical determinants of this support ratio, or of ALMP expenditures as a simple share of GDP, are too powerful. They yield highly sensitive results, even when this support ratio is estimated with only those instruments that should not have been very cyclical. In some variants, ALMP was wildly sensitive to GDP. We have to leave this variable out, relying on continuing micro-based research to determine its role.

Openness to trade, like ALMP, runs the risk of being highly endogenous and responsive to the business cycle, especially if it is measured as trade shares of GDP. We seek only the policy component of openness, and chose the Freedom House indicator of how open are government and the law to international transactions. This was not easily instrumented, and was viewed as exogenous. 


\section{APPENDIX B. FULL REGRESSIONS BEHIND FOUR EQUATIONS OF TABLE 2}

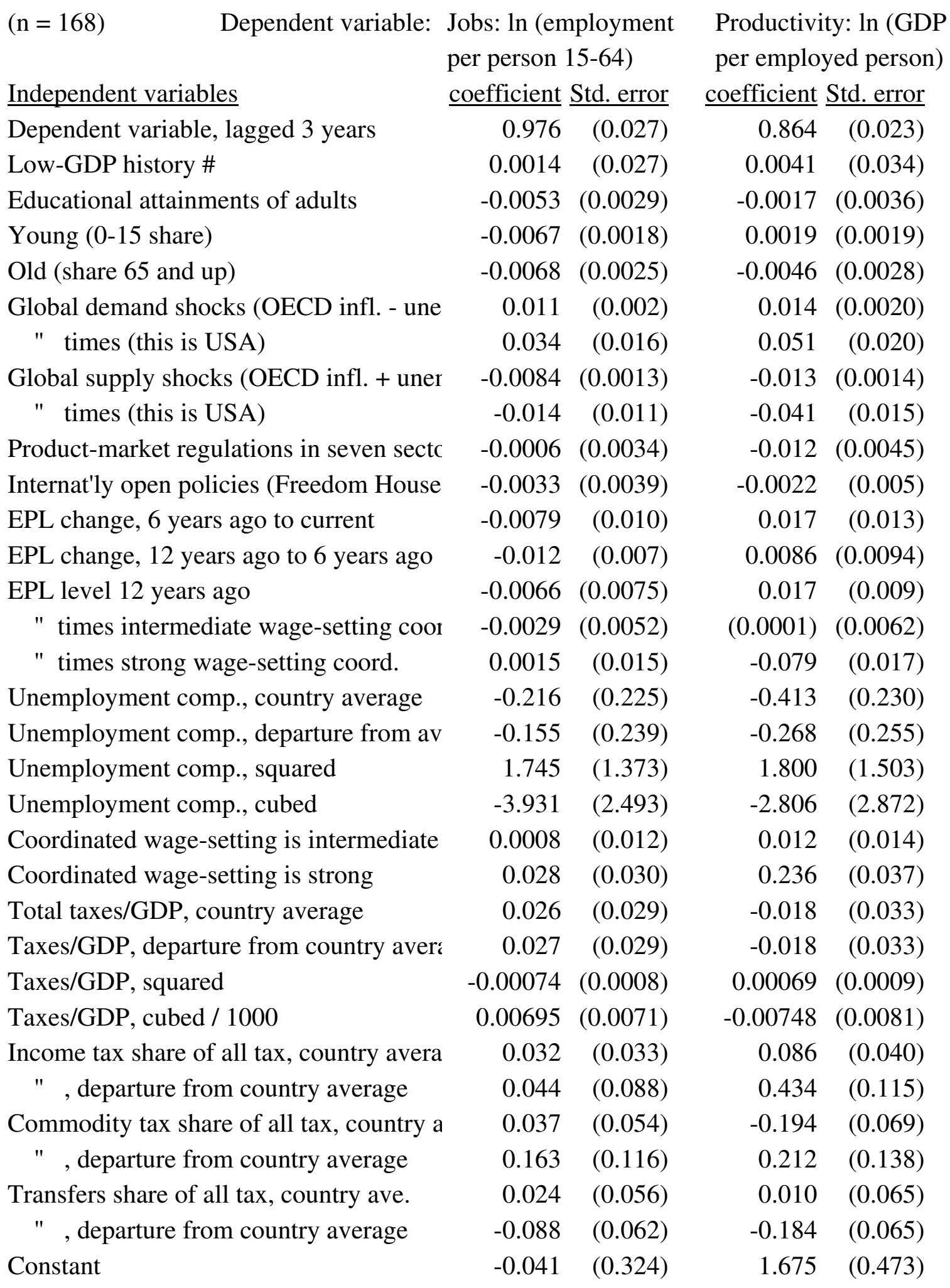


Mean of dependent variable

$-0.428$

10.578

\# Low-GDP history = ln (US GDP per cap. / this country's GDP per cap.), 10 years earlier.

(For choices of IV's, see Table 1 and Appendix A.)

\section{APPENDIX B. FULL REGRESSIONS BEHIND TABLE 2, continued}

\begin{tabular}{|c|c|c|c|c|}
\hline Dependent variable: & $\begin{array}{l}\text { Output: } \ln ( \\
\text { per person }\end{array}$ & $\begin{array}{l}\text { GDP } \\
5-64)\end{array}$ & $\begin{array}{l}\text { Growth: } 3 \\
\text { in } \log (\mathrm{GD}\end{array}$ & $\begin{array}{l}\text { year change } \\
\text { per capita) }\end{array}$ \\
\hline$\underline{\text { Independent variables }}$ & $\underline{\text { coefficient }}$ & Std. error & $\underline{\text { coefficient }}$ & Std. error \\
\hline Dependent variable, lagged 3 years & 0.757 & $(0.042)$ & & \\
\hline Low-GDP history \# & -0.031 & $(0.055)$ & 0.096 & $(0.032)$ \\
\hline Educational attainments of adults & -0.0027 & 0.0055 & -0.0012 & 0.0035 \\
\hline Young (0-15 share) & -0.0086 & 0.0032 & -0.0006 & 0.0018 \\
\hline Old (share 65 and up) & -0.015 & 0.0045 & -0.0049 & 0.0028 \\
\hline Global demand shocks (OECD infl. - une & 0.026 & 0.0032 & 0.0149 & 0.0020 \\
\hline$"$ times (this is USA) & 0.068 & $(0.032)$ & 0.066 & $(0.022)$ \\
\hline Global supply shocks (OECD infl. + uner & -0.024 & $(0.0023)$ & -0.014 & $(0.0013)$ \\
\hline$"$ times (this is USA) & -0.073 & $(0.024)$ & -0.041 & $(0.017)$ \\
\hline Product-market regulations in seven sectc & -0.022 & $(0.0074)$ & 0.0030 & $(0.0040)$ \\
\hline Internat'ly open policies (Freedom House & -0.013 & $(0.0075)$ & -0.0018 & $(0.0053)$ \\
\hline EPL change, 6 years ago to current & -0.0019 & $(0.019)$ & -0.0021 & $(0.0128)$ \\
\hline EPL change, 12 years ago to 6 years ago & -0.023 & $(0.014)$ & 0.0091 & $(0.0094)$ \\
\hline EPL level 12 years ago & -0.013 & $(0.014)$ & 0.0051 & $(0.0091)$ \\
\hline " times intermediate wage-setting coor & 0.0089 & 0.0092 & 0.0006 & $(0.0064)$ \\
\hline " times strong wage-setting coord. & -0.040 & $(0.027)$ & -0.042 & $(0.016)$ \\
\hline Unemployment comp., country average & -0.864 & $(0.364)$ & -0.189 & $(0.232)$ \\
\hline Unemployment comp., departure from av & -0.636 & $(0.400)$ & -0.073 & $(0.258)$ \\
\hline Unemployment comp., squared & 4.039 & $(2.281)$ & 1.389 & $(1.465)$ \\
\hline Unemployment comp., cubed & -6.725 & $(4.249)$ & -2.906 & $(2.702)$ \\
\hline Coordinated wage-setting is intermediate & -0.0047 & $(0.021)$ & 0.0049 & $(0.015)$ \\
\hline Coordinated wage-setting is strong & 0.204 & $(0.058)$ & 0.154 & $(0.034)$ \\
\hline Total taxes/GDP, country average & 0.029 & $(0.053)$ & 0.058 & $(0.034)$ \\
\hline Taxes/GDP, departure from country aver & 0.029 & $(0.053)$ & 0.055 & $(0.033)$ \\
\hline Taxes/GDP, squared & -0.0008 & 0.0015 & -0.0014 & 0.0009 \\
\hline Taxes/GDP, cubed / 1000 & 0.0077 & 0.0131 & 0.0117 & 0.0082 \\
\hline Income tax share of all tax, country avera & 0.075 & $(0.061)$ & 0.096 & $(0.039)$ \\
\hline$"$, departure from country average & 0.691 & $(0.179)$ & 0.323 & $(0.115)$ \\
\hline Commodity tax share of all tax, country a & -0.198 & $(0.104)$ & -0.205 & $(0.074)$ \\
\hline
\end{tabular}


" , departure from country average

Transfers share of all tax, country ave.

$"$, departure from country average

Constant

$\begin{array}{rrrr}0.478 & (0.210) & 0.317 & (0.142) \\ 0.111 & (0.099) & -0.026 & (0.070) \\ -0.176 & (0.103) & -0.255 & (0.068) \\ 2.740 & (0.743) & -0.655 & (0.370)\end{array}$

10.151

0.065

\# Low-GDP history = ln(US GDP per cap./this country's GDP per cap.), 10 years earlier.

(For choices of IV's, see Table 1 and Appendix A.) 